
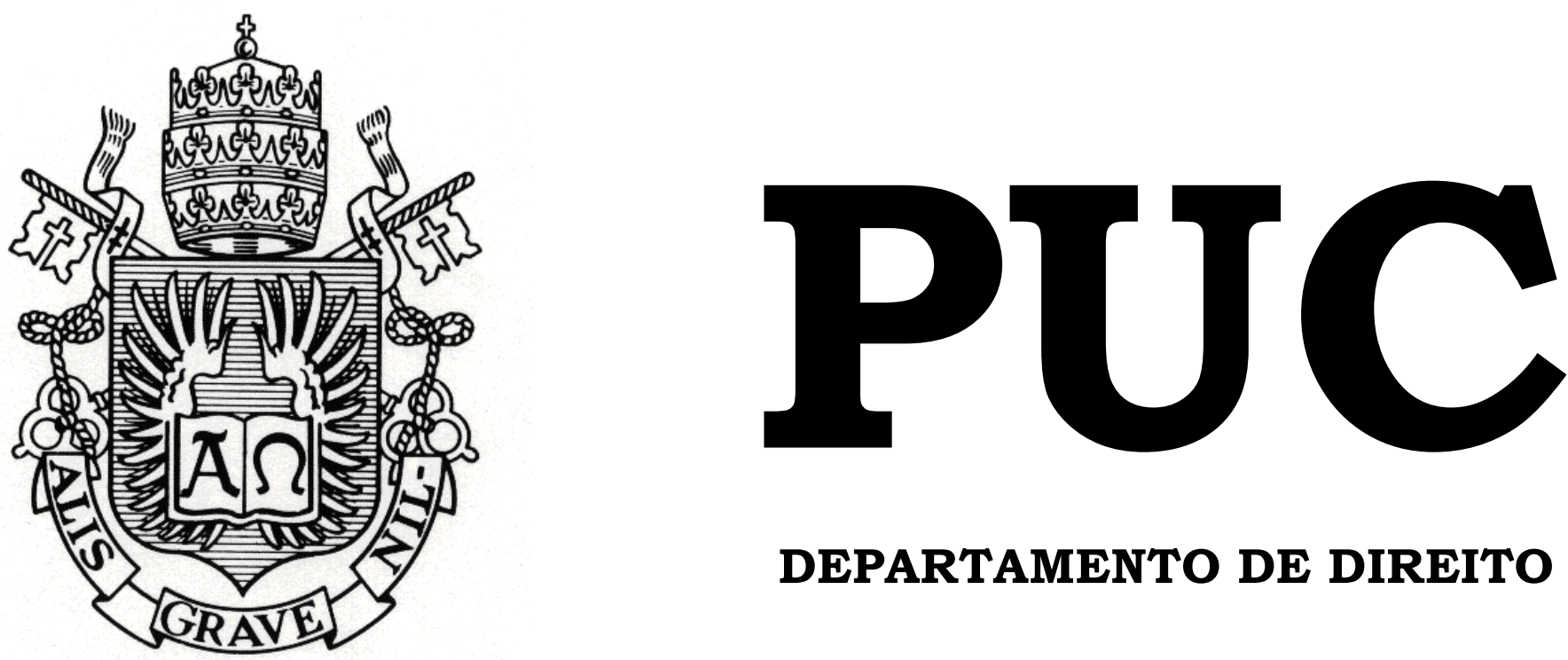

DEPARTAMENTO DE DIREITO

O CASAMENTO HOMOAFETIVO NO BRASIL

por

MARINA VILLELA PEDRAS POLONIA

ORIENTADORA: INÊS ALEGRIA ROCUMBACK

2011.1

PONTIFÍCIA UNIVERSIDADE CATÓLICA DO RIO DE JANEIRO

RUA MARQUÊS DE SÃO VICENTE, 225 - CEP 22453-900

RIO DE JANEIRO - BRASIL 


\section{O CASAMENTO HOMOAFETIVO NO BRASIL}

por

\section{MARINA VILLELA PEDRAS POLONIA}

Monografia

apresentada

ao

Departamento de Direito da Pontifícia Universidade Católica do Rio de Janeiro (PUC-Rio) para a obtenção do Título de Bacharel em Direito.

Orientadora: Inês Alegria Rocumback 
"CADA UM SABE A DOR E A DELÍCIA DE

SER O QUE É"- CAETANO VELOSO 
Dedico o presente trabalho a todos que são condenados à invisibilidade jurídica e à discriminação social pelo simples fato de amar o igual. 


\section{AGRADECIMENTOS}

"Quem acredita sempre alcança."- Renato Russo

Impossível resumir em uma folha os mais sinceros agradecimentos que devo a tantas pessoas. No entanto, não posso deixar de mencionar algumas extraordinárias que me ajudaram a construir o que eu penso, o que eu quero e, principalmente, o que eu sou.

Aos meus avôs maternos JOSÉ AUGUSTO VILLELA PEDRAS e EDNÉA por desde sempre acreditarem no meu potencial. À minha mãe SANDRA pela obviedade que prescinde qualquer explicação. A NADIR, ex-babá e terceira mãe, pela presença constante em minha vida.

A mais sincera admiração dedico a MÔNICA AZEVEDO MONTENEGRO, incomparável profissional que me apresentou o caminho da Defensoria Pública.

\section{À minha orientadora INÊS ALEGRIA ROCUMBACK.}

Agradeço a DEUS pela força nos momentos de fraqueza, pela certeza nos momentos de dúvida e pela auto confiança nos momentos de descrença.

Aos meus melhores amigos, aos professores de Direito da PUC-RIO, aos funcionários do Departamento e do NPJ, A TODOS MUITO OBRIGADA!

Sinto-me realizada por conseguir, mais uma vez, terminar tudo que um dia comecei. 


\section{RESUMO}

POLONIA, Marina Villela Pedras. O casamento homoafetivo no Brasil. Rio de Janeiro: PUC-Rio, 2011 85p. (Monografia - Departamento de Direito)

O questionamento sobre a possibilidade jurídica do casamento civil homoafetivo no Brasil é o cerne deste trabalho. Pretende-se demonstrar a sua viabilidade com base na Constituição Federal, no Código Civil, no Código de Processo Civil, na Lei Maria da Penha, e, ainda, em sede de doutrina e jurisprudência.

Para isso, o trabalho se organiza em três etapas, divididas em seis capítulos. A primeira parte analisa o reconhecimento das novas formas de entidades familiares e também se destina à contextualizar a proteção constitucional da homossexualidade destacando, ainda, alguns aspectos do discurso religioso da Igreja Católica e o princípio da laicidade do Estado. A segunda parte analisa a possibilidade jurídica do casamento homoafetivo em razão de lacuna legislativa, parte central da presente tese, e, ainda, uma análise do tema sob a ótica do Direito Comparado. A terceira e última parte, por sua vez, tem como foco o avanço positivo no Brasil da experiência legislativa e jurisprudencial, através da Lei Maria da Penha e das recentes

decisões dos Tribunais brasileiros, do STJ e STF relacionadas à homoafetividade.

PALAVRAS-CHAVE: Direito; Homoafetividade; Família; Casamento. 


\section{SUMÁRIO}

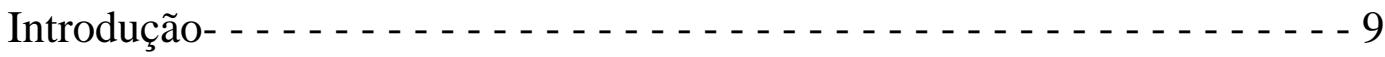

Reconhecimento de novas formas de entidade familiar - - - - - - - - - -12

Homoafetividade, Estado Laico e Igreja Católica - - - - - - - - - - - - - 22

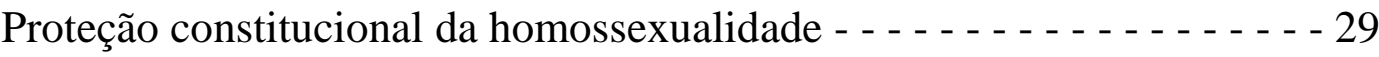

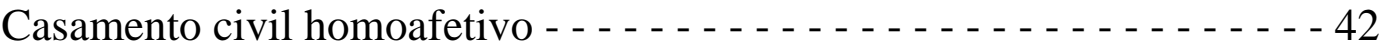

Direito Comparado: recepção do tema no sistema jurídico internacional - 53

Experiência brasileira: decisões, legislação e jurisprudência - - - - - - - 64

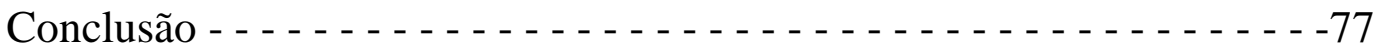

Referências Bibliográficas- - - - - - - - - - - - - - 81

Anexo I - _ - $\ldots$ 


\section{LISTA DE REDUÇÕES}

ADPF Arguição de Descumprimento de Preceito Fundamental

ADI Ação Direta de Inconstitucionalidade

Art

Artigo

$\mathrm{CC}$

Código Civil

CF 88 Constituição da República Federativa do Brasil de 1988

CPC Código de Processo Civil

IBGE Instituto Brasileiro de Geografia e Estatística

LGBT Lésbicas, Gays, Bissexuais e Transgêneros

LICC Lei de Introdução ao Código Civil

LMP Lei Maria da Penha

MPF Ministério Público Federal

STF Supremo Tribunal Federal

STJ Superior Tribunal de Justiça 


\title{
INTRODUÇÃO
}

\author{
"Época triste a nossa, em que é mais difícil quebrar \\ um preconceito do que um átomo.”-Albert Einstein
}

Não foi difícil escolher um tema para a minha monografia. Apaixonada pelo Direito das Famílias e indignada pelo fato do Código Civil de 2002 ter nascido velho neste ramo, o meu trabalho surgiu diante a perplexidade do fato de casais homossexuais não poderem casar civilmente no Brasil. Será que há um verdadeiro impedimento para que não se tutele tal união????

\section{A homossexualidade é uma histórica, notável e inquestionável} realidade. Trata-se de matéria atual e de grande repercussão dentro da sociedade. E, não obstante as recentes produções acadêmicas neste tema, ainda persiste a necessidade de mobilização e debate a fim de alcançarmos uma alteração na lei e no repúdio das pessoas.

Sendo um fato social, a homossexualidade antecede a lei. Na verdade, ela existe desde as épocas mais remontas da humanidade, o que antecede qualquer padrão de conduta que o legislador tenha imaginado inserir em moldes normativos. Com efeito, a regulação destas uniões afetivas torna-se uma preocupação mundial e essas distintas maneiras de vivenciar o afeto demandam não apenas o reconhecimento da coletividade, mas também e, principalmente, o reconhecimento jurídico.

No presente estudo se utilizará no lugar de homossexualidade, o vocábulo HOMOAFETIVIDADE. ${ }^{1}$ Foram os homoafetivos, por muito tempo, marginalizados. Hoje, continuam sendo, mas em menor intensidade. Nos últimos anos, a sociedade vem se mostrando mais tolerante e

\footnotetext{
${ }^{1}$ Neologismo criado pela Maria Berenice Dias em 2000 na $1^{\text {a }}$ edição da obra União homossexual: o preconceito e a justiça.
} 
modificando suas próprias “aceitações”. É a evolução do pensamento, do comportamento, dos costumes, dos conceitos e dos valores.

A verdade é que a despeito de moralismos ou preconceitos, uma nova realidade se impõe e não há como negá-la. O IBGE comprova tal fato. $\mathrm{O}$ Instituto incluiu questionamento sobre a relação do entrevistado com o responsável pelo domicílio, tendo sido inserida a opção companheiro do mesmo sexo. No censo 2010, mais de sessenta mil brasileiros declararam viver com companheiro do mesmo sexo. $\mathrm{O}$ Estado não pode ficar inerte ignorando esta realidade. Desamparados e sem lei protetora explícita, os homossexuais começaram a buscar justiça visando adquirir visibilidade jurídica a fim de obtenção de seus próprios direitos.

É o que argumenta Maria Berenice Dias:

"Nenhum estado contemporâneo pode ignorar essa realidade cada vez mais transparente, pois não se trata de uma questão isolada ou frouxidão dos costumes, como querem os moralistas, e sim expressão da sexualidade que qualquer estado democrático tem o dever de respeitar" (DIAS, 2009:29)

Não há dúvida de que os fatos sociais falam mais alto que o preconceito, mas enquanto as relações homoafetivas não sejam incluídas expressamente no texto legal, o que teremos serão famílias desprotegidas e direitos cerceados. Nestas condições, pretendo, na presente monografia, ultrapassar o argumento da superação do preconceito e desenvolver uma consistente argumentação jurídica a fim de, por si só, romper barreiras e construir direitos.

Por outro lado, não proponho delimitar a história da homossexualidade. O objetivo é desenvolver o atual entendimento do panorama jurídico e legal da homoafetivide independente de sua causa ou raízes históricas. "A origem não se conhece. Aliás, nem interessa, pois, quando se buscam causas, parece que se está atrás de um remédio, de um 
tratamento para encontrar cura para algum mal”. (DIAS, 2007:186) Na mesma linha, não se abordarão situações específicas envolvendo a adoção por casal homoafetivo, bem como as questões de travestis, transexuais ou mesmo a reprodução humana assistida, que mesmo tangentes ao tema, remetem-se à exames jurídicos conexos, esquivando dos objetivos delimitados neste trabalho.

Para o desenvolvimento desta obra, participei do I SEMINÁRIO DE DIVERSIDADE SEXUAL realizado na PUC-RIO no dia 17 de maio de 2010 e do I CONGRESSO NACIONAL DE DIREITO HOMOAFETIVO, realizado no prédio da OAB do Rio de Janeiro nos dias 23, 24 e 25 de março de 2011

Ademais, a metodologia adotada teve como base pesquisas bibliográficas nacionais e internacionais. Há de se fazer referência especial a dois livros lançados em 2011 que serviram como alicerce: DIVERSIDADE SEXUAL E DIREITO HOMOAFETIVO, da renomada MARIA BERENICE DIAS e HOMOAFETIVIDADE E DIREITO, da autora MARIANNA CHAVES. Foram estudadas as legislações pertinentes, bem como as recentes decisões jurisprudenciais e utilizadas informações obtidas em revistas, jornais e pesquisas online a partir de cadastros em sites especializados em Direito de Família.

De fato, se o futuro já chegou, é preciso mudar a história que se funda em um passado discriminador e segregatório. 


\title{
RECONHECIMENTO DE NOVAS FORMAS DE ENTIDADE FAMILIAR
}

“Consideramos justa toda a forma de amor"- Lulu Santos

Antigamente a família brasileira era somente aquela oriunda do matrimônio entre um homem e uma mulher, com seus descendentes comuns. Não havia a preocupação com o amor, com o bem-estar, e nem com a felicidade dos seus membros. A finalidade da constituição de família era, em resumo, legalizar as relações sexuais, procriar e transmitir o patrimônio. $\mathrm{O}$ chefe da sociedade conjugal era o homem, cabendo a ele prover a subsistência além de exercer o total domínio sobre a família. A mulher casada era considerada incapaz e à ela era atribuída somente a função doméstica.

\begin{abstract}
"Até meados do século XX, a humanidade era regida por um sistema jurídico que valorizava uma visão extremamente patrimonialista da vida humana. A família, tida como um fim em si mesmo, visava unicamente a garantir a perpetuação da espécie e que os bens do homem fossem herdados por alguém que fosse efetivamente seu descendente, "do seu sangue", donde se valorizava sobremaneira a virgindade da mulher. Afinal, como as técnicas de verificação da paternidade da época não forneciam uma posição precisa no que tange à filiação, a virgindade feminina anterior ao casamento passou a ser vista como requisito de respeitabilidade da mulher, justamente para garantir a certeza da filiação masculina. "(VECCHIATTI, 2008:147)
\end{abstract}

O CC 1916, por sua vez, estabelecia como sendo o casamento civil a única forma de se compor uma família legítima, em um vínculo que era, também, indissolúvel. Assim, quaisquer uniões amorosas que não fossem culminadas pelo instituto do casamento civil, mesmo as entre heteroafetivos, eram consideradas ilegítimas e sem, portanto, qualquer proteção da lei. Tal fato revela a forte influência da Igreja sob o Estado, considerando que o casamento religioso também é indissolúvel e a única união legítima perante Deus. 
Contudo, o conceito de família se modifica com o passar do tempo. Sua função econômica perde o sentido e a procriação não é mais sua finalidade, o patrimônio não é mais a sua base, a mulher não é mais considerada incapaz ao casar-se, conforme instituído pelo Estatuto da Mulher Casada em 1962. Destarte, houve a emancipação econômica, social e jurídica desta, que passa a comandar a família conjuntamente com o homem.

A CF de 1988 entende a família como a base da sociedade brasileira: "Art. 226: A família, base da sociedade, tem especial proteção do Estado.". E atualmente não existe apenas como estrutura familiar a chamada família nuclear, aquela formada por pais e seus filhos. São reconhecidas, também, outras modalidades de família, tais como a monoparental ${ }^{2}$, anaparental ${ }^{3}$ mosaico ${ }^{4}$, entre outras. Assim, pode-se afirmar que houve uma verdadeira reformulação do modelo tradicional de família, não existindo, pois, um padrão a ser seguido. $\mathrm{O}$ ato sacramental do casamento deixa de ser um requisito essencial para a constituição de uma família.

Além das formas de família cujo artigo 226 da CF reconhece, a Lei Maria da Penha trouxe uma conceituação mais ampla, acompanhando as modificações sociais e, inclui, ainda, as uniões entre pessoas do mesmo sexo. Em seu artigo $2^{\circ}$, é disposto o seguinte: "Toda mulher,

\footnotetext{
${ }^{2}$ as famílias monoparentais constituem um exemplo de entidade familiar fora do contexto da conjugalidade. Seja oriunda de uma adoção singular, seja oriunda de uma procriação medicamente assistida, seja originária de uma reprodução natural sem reconhecimento do respectivo pai, ou originária do falecimento de um dos progenitores, a entidade constituída pelo filho com qualquer ou apenas um de seus pais configura uma família. (CHAVES, 2011:98-99)

${ }^{3}$ como exemplo ilustrativo, poder-se-ia citar a convivência duradoura de dois irmãos que reúnem esforços para construção do patrimônio. Entende-se na doutrina brasileira que, no caso de falecimento de um deles, é iníqua a solução de dividir o patrimônio igualmente entre todos os irmãos, como herdeiros colaterais, em nome da ordem de vocação hereditária. (CHAVES, 2011:98-99)

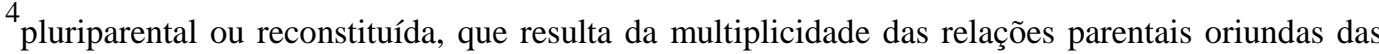
desuniões, do divórcio, da separação, da reconstituição da vida afetiva por meio do casamento ou relações paramatrimoniais. A especificidade desse modelo familiar origina-se na peculiar estrutura do núcleo, formado por pares onde um ou ambos tiveram uniões ou casamentos anteriores. Trazem consigo, para a nova entidade familiar, sua prole e, não raras vezes, têm filhos em comum. É a clássica expressão: os meus, os teus, os nossos. (CHAVES, 2011:98-99)
} 
independentemente de classe, raça, etnia, orientação sexual, renda, cultura, nível educacional, idade e religião, goza dos direitos fundamentais inerentes à pessoa humana, sendo-lhe asseguradas as oportunidades $e$ facilidades para viver sem violência, preservar sua saúde física e mental e seu aperfeiçoamento moral, intelectual e social."

O parágrafo único do artigo $5^{\circ}$, por sua vez, menciona de forma explícita, que as situações que configuram violência familiar a e doméstica independem da orientação sexual das pessoas envolvidas:

\begin{abstract}
"Art 5": Para os efeitos desta Lei, configura violência doméstica e familiar contra a mulher qualquer ação ou omissão baseada no gênero que the cause morte, lesão, sofrimento físico, sexual ou psicológico e dano moral ou patrimonial: I- no âmbito da unidade doméstica, compreendida como o espaço de convivio permanente de pessoas, com ou sem vínculo familiar, inclusive as esporadicamente agregadas; II - no âmbito da família, compreendida como a comunidade formada por indivíduos que são ou se consideram aparentados, unidos por laços naturais, por afinidade ou por vontade expressa. III - em qualquer relação íntima de afeto, na qual o agressor conviva ou tenha convivido com a ofendida, independentemente de coabitação.
\end{abstract}

Parágrafo único. As relações pessoais enunciadas neste artigo independem de orientação sexual."

Conclui Maria Berenice Dias:

"Se a negativa de emprestar direitos às uniões homoafetivas tinha por fundamento a ausência de lei, esta desculpa já não serve mais. A Lei Maria da Penha, de forma até repetitiva (LMP $2 .^{\circ}$ e $5 .^{\circ}$ parágrafo único), ressalva a orientação sexual de quem se sujeita à violência doméstica. Como a lei veio proteger a mulher vítima da violência doméstica familiar, definiu e albergou no seu conceito as uniões homoafetivas (...)." (DIAS, 2007:46)

“(...) restam completamente esvaziados todos os projetos de lei em tramitação e que visam a regulamentar a união civil ou a parceria civil registrada. Esses projetos perderam o objeto, uma vez que há lei conceituando entidade familiar, não importando a orientação sexual de seus partícipes." (DIAS, 2007:191)

Ao apontar que a família se compreende como a comunidade formada por indivíduos que são ou se consideram aparentados por vontade expressa ou vínculo de afinidade e que as relações pessoais enunciadas em tal artigo independem de orientação sexual, a LMP abarca as uniões homoafetivas já que estas representam, justamente, essa união de duas 
pessoas que se consideram unidas por vontade expressa ou vínculo de afinidade. Assim, como é garantida uma proteção legal a fatos ocorridos em ambientes domésticos, conclui-se que uniões homoafetivas são entidades familiares. Deste modo, a LMP estendeu o conceito de família. Do contrário, as relações dispostas no artigo dependeriam da orientação sexual o que iria de encontro ao parágrafo único do dispositivo legal.

Em outras palavras, se a violência doméstica somente pode ocorrer dentro âmbito familiar e se as relações pessoais, das quais trata o artigo, independem de orientação sexual, conclui-se que a lei admite a existência de família homoafetiva. Por outro lado, tendo em vista que a LMP só se refere à violência contra mulheres, e não contra homens, poderia sugerir que somente reconheceria as uniões homoafetivas femininas.

De fato, as punições previstas nesta Lei devem ser aplicadas somente à violência cometida contra mulheres. Contudo, considerando que as uniões homoafetivas femininas e masculinas têm caráter familiar idêntico, através do princípio da igualdade, deveria haver a interpretação extensiva do conceito de família já trazido aos casais homoafetivos femininos pela LMP aos casais homoafetivos masculinos. Isso porque se é a união entre duas mulheres é considerada família, pela isonomia, a união entre dois homens também constitui família.

É o que justifica Maria Berenice Dias em seu artigo "A invisibilidade das uniões homoafetivas e a omissão da Justiça":

\footnotetext{
"Ao ser afirmado que está sob o abrigo da Lei a mulher, sem distinguir sua orientação sexual, encontra-se assegurada proteção tanto às lésbicas como às travestis, as transexuais e os transgêneros do sexo feminino, que mantêm relação intima de afeto, em ambiente familiar ou de convívio. Em todos esses relacionamentos, as situações de violência contra o gênero feminimo justificam especial proteção. Ao depois a lei define como família qualquer relação íntima de afeto (art. $5^{\circ}$, III), o que não permite excluir as homoafetivas deste conceito. Às claras que os vínculos constituídos por pessoas do mesmo sexo são uma sociedade de afeto. Assim, é imperioso reconhecer que as uniões homoafetivas constituem uma entidade familiar. Quer as uniões formadas por um homem e
} 
uma mulher, quer as formadas por duas mulheres, quer as formadas por um homem e uma pessoa com distinta identidade de gênero, todas configuram famílias. Ainda que a lei tenha por finalidade proteger a mulher, fato é que ampliou o conceito de família, independentemente do sexo dos parceiros. Se também família é a união entre duas mulheres, igualmente é família a união entre dois homens. Basta invocar o princípio da igualdade."

Nestas circunstâncias, a lacuna legal quanto as reconhecimento do status jurídico-familiar das relações homoafetivas, foi perfeitamente preenchida pela Lei Maria da Penha. Para Maria Berenice Dias:

"A partir da nova definição de entidade familiar, trazida pela Lei Maria da Penha, não mais cabe questionar a natureza dos vínculos formados por pessoas do mesmo sexo. É família. Ninguém pode continuar sustentando que, em face da omissão legislativa, não é possível emprestar-lhes efeitos jurídicos. Há um novo conceito de família. Em face da normatização levada a efeito, restam completamente esvaziados todos os projetos de lei em tramitação que visam regulamentar a união civil ou a parceria civil registrada. Esses projetos perderam o objeto, uma vez que há lei que conceitua entidade familiar, não importando a orientação sexual dos partícipes." (DIAS, 2009:141-142)

Neste mesmo sentido, afirma Marianna Chaves:

"Coerente com essa idéia, é o fato de se poder afirmar que as uniões homoafetivas constituem um núcleo familiar e, como tal, fazem emergir reflexos jurídicos de toda sorte. Seja pela constituição (ou desejo de constituição) da união, seja pelo seu término, seja pela parentalidade exercida por um ou ambos do par, os efeitos jurídicos são infindáveis e nem sempre tutelados da forma adequada. $O$ Judicial, em especial o brasileiro, em virtude da falta de regulação normativa, não pode seguir oferecendo 'respostas mortas a perguntas vivas', afastandos-se do Direito justo, cingindo-se a formalismos e desconhecendo a realidade social subjacente." (CHAVES, 2011:34)

Essa mudança de pensamento advém da compreensão da família como sinônimo de crescimento, amadurecimento e envelhecimento juntos. E tendo o afeto como um valor jurídico, não há como deixar de admitir a possibilidade do casamento civil como um direito de gays e lésbicas. Como afirma Maria Berenice Dias em um julgado do Tribunal sulista ${ }^{5}$ a ausência de lei específica não significa inexistência de direitos, não podendo o juiz deixar de reconhecê-los.

\footnotetext{
${ }^{5}$ RIO GRANDE DO SUL. Tribunal de Justiça. Apelação Cível numero 70009550070 ,
} RELATOR: MARIA BERENICE DIAS, julgado em 17.11.2004 
Sobre a afetividade, o autor Pedro Belmiro Welter:

"o afeto está para o Direito da Família, assim como a posse e o domínio estão para o Direito das Coisas; o liame contratual, para o Direito Obrigacional; o fato delituoso, para o Direito Penal; o vínculo laboral, para o Direito do trabalho"(WELTER, 2002:237)

Neste mesmo sentido, a autora Marianna Chaves:

"Em virtude da mudança epistemológica ocorrida no ânimo da família, a ordem jurídica passou a considerar o afeto como um valor jurídico de relevante prestígio para o direito das famílias. Seus reflexos vêm penetrando em todo o ordenamento jurídico como, p.e, na valorização dos laços de afetividade e da convivência familiar originárias da filiação, em prejuízo, muitas vezes, dos lados biológicos" (CHAVES, 2011:230)

Segundo Vecchiatti, a prova definitiva de que o amor é fundamental para a caracterização da família juridicamente protegida é que relacionamentos de amizade estáveis não geram uniões estáveis no conceito técnico-jurídico de entidade familiar. (VECCHIATTI, 2008:242)

Nestas condições, pode-se assegurar que a família é a base da estrutura social e plenitude do bem-estar do ser humano. E o desafio dos tempos modernos é reconhecer o afeto como o sinalizador das relações interpessoais a fim de denominá-las, sem qualquer receio, como família.

Pode-se, ainda, citar a questão das relações extramatrimoniais e a dos filhos nascidos fora do casamento. Eram situações antes repelidas e ignoradas que, com a evolução dos tempos e a pressão dos fatos, passaram a gerar reconhecimento e conseqüente aceitação social. Desta forma, o legislador se deparou com a necessidade de disciplinar tais realidades, as normativizando.

Mas foi com a Lei 9278/96, depois reproduzida no artigo 1.723 do CC, que foi conceituada: "É reconhecida como entidade familiar a união 
estável entre o homem e a mulher, configurada na convivência pública, contínua e duradoura e estabelecida com o objetivo de constituição de família." As uniões estáveis passaram a ser consideradas entidades familiares constitucionalmente protegidas desde 1988 com a CF. Aos filhos, por sua vez, é garantido um tratamento isonômico, independente de sua origem, não sendo mais admitido o uso de adjetivações como "filho legítimo", "filho bastardo", entre outras.

Contudo, alguns magistrados, em momentos anteriores da recente decisão vinculante do $\mathrm{STF}^{6}$, ainda reconheciam as uniões homoafetivas como sendo uma sociedade de fato, como se a finalidade de tais relações fosse o aspecto patrimonial e não uma conseqüência do afeto. Não haveria, então, o direito de pleitear alimentos, bem como os direitos sucessórios ou benefícios precidenciários. Um absurdo. Ao companheiro sobrevivente, no caso, seria deferido, no máximo, metade do patrimônio adquirido durante a união e apenas se comprovasse o esforço comum, conforme súmula 380 do STF que dispõe: "Comprovada a existência de sociedade de fato entre os concubinos, é cabivel a sua dissolução judicial, com a partilha do patrimônio adquirido pelo esforço comum.".

Como adverte Paulo Lôbo, não é necessário degradar a natureza pessoal de família transformando-a em ilusória sociedade de fato, como se seus partícipes fossem sócios de algum tipo de empreendimento lucrativo. (LÔBO, 1999-103)

Neste sentido, Maria Berenice Dias em seu artigo "Amor não tem sexo":

"Ainda que de forma tímida e conservadora, e mais por não conseguir a Justiça conviver com a mais chocante injustiça, que é o enriquecimento injustificado, o afeto começou a receber respaldo jurisdicional. No princípio, confundindo-se amor com lavor, e as relações chamadas concubinárias foram vistas como verdadeiros vínculos empregatícios. Depois, identificado como sociedade de fato o que nada mais era do que uma sociedade de afeto, as relações

\footnotetext{
${ }^{6}$ Decisão vinculante de maio de 2011 que será melhor analisada no último capítulo do
} presente trabalho. 
extramatrimoniais foram inseridas no Direito Obrigacional. Um verdadeiro negócio jurídico, segundo o art. 981 do CC, uma combinação de esforços ou recursos para lograr fins comuns. O respaldo judicial concedido às relações extramatrimoniais acabou levando a Constituição Federal a alargar o conceito de família. Não exclusivamente ao casamento o legislador constituinte emprestou $o$ nome de entidade familiar. Também assim chamou a união estável $e$ as relações de um dos pais com seus filhos. Embora vanguardista, o conceito de família cunhado pela Lei Maior ainda é acanhado, pois não logrou envolver vínculos afetivos outros, que não correspondem ao paradigma convencional: casamento, sexo e reprodução.(...)Passaram a ser considerados família os relacionamentos não identificados pelo casamento. Em face do atual estágio da evolução da engenharia genética, a reprodução não mais depende da ocorrência de contato sexual. Assim, imperioso que se busque um novo conceito de família"

Devemos atentar, ainda, para a atual repersonalização do Direito das Famílias que objetiva superar uma concepção patrimonialista das relações familiares, a fim de possibilitar a abertura para a pluralidade de formas conjugais e familiares existentes. Verifica-se uma visão eudemonista de família na qual "não é mais o indivíduo que existe para a família e para o casamento, mas sim a família e o casamento é que existem para o seu desenvolvimento pessoal, em busca de sua aspiração à felicidade" (FILHO, 2007: 62).

Neste sentido, Marianna Chaves:

"Numa lógica de Estado Democrático de Direito, é possível asseverar que os ordenamentos jurídicos em estudo (nomeadamente o português e o brasileiro) possuem todas as ferramentas para lidar de forma coerente e ajustada com as novas formas de arranjos familiares e afetivos que demandam a proteção da justiça. Tal possibilidade também emerge pela repersonalização do Direito das Famílias, onde se afasta da leitura substancialmente patrimonialista das relações familiares. Todo e qualquer país que se diga democrático e guardião dos direitos humanos não deve, nem pode, compactuar com discriminações arbitrárias, como é o caso da discriminação por razão de sexo ou em virtude da orientação sexual. Como já diria o eminente Ministro do STJ basileiro, Sálvio de Figueiredo Teixeira no início dos anos 90, 'o fetichismo das normas legais em atrito com a evolução social e científica, não podde uma prevalecer a ponto de levar o Judiciário a manifestar-se em face de uma realidade mais palpitante", (CHAVEZ, 2011:33)

\section{E Maria Berenice Dias:}

"a entidade familiar, apesar do que muitos dizem, não se mostra em decadência. Ao contrário, é o resultado das transformações sociais. Houve a repersonalização das relações familiares na busca do atendimento aos interesses mais valiosos das pessoas humandas: afeto, solidariedade, lealdade, confiança, 
respeito e amor. Ao Estado, inclusive nas suas funções legislativas $e$ jurisprudenciais, foi imposto o dever jurídico constitucional de implementar medidas necessárias e indispensáveis para a constituição e desenvolvimento das famílias". (DIAS, 2007:34)

Por outro lado, devemos ponderar que o legislador considerou apenas a forma heteroafetiva como família digna de proteção ao estipular "homem e mulher" no citado artigo 1.723 do CC, como também nos artigos 1.514, 1.517 e 1.565, e, ainda, no artigo 226 da CF (dispositivos que serão melhores analisados em capítulo próprio). De fato, a homossexualidade era tratada como um desvio, uma doença. Tal entendimento foi completamente ultrapassado e o que hoje temos é uma lacuna normativa oriunda da ignorância conceitual do legislador acerca do tema.

Essa é também a leitura de Vecchiatti:

"O legislador pretendeu proteger o amor familiar com o casamento civil e com a união estável. Para tanto, visualizou apenas a forma heteroafetiva como família digna de proteção. Esta concepção decorreu, ressalte-se, da equivocada compreensão que perdurou até o final do século $X X$, no sentido de que a homossexualidade era uma "doença", um "desvio" ou uma "perversão". Contudo, esse entendimento foi ultrapassado pela Organização Mundial de Saúde e pelos nossos Conselhos Federais de Medicina e Psicologia, que aduzem não ser a homossexualidade uma doença, um desvio psicológico nem uma perversão, mas uma das livres manifestações da sexualidade humana, ao lado da heterossexualidade. Se o legislador tivesse essa compreensão, certamente teria deixado expresso que as uniões homoafetivas são protegidas pelo casamento civil e pela união estável, uma vez que formam entidades familiares da mesma forma que o fazem as uniões heteroafetivas. Assim, temos aqui uma lacuna normativa oriunda da ignorância conceitual do legislador acerca do tema da homossexualidade." (VECCHIATTI, 2008:367)

E de Maria Berenice Dias:

"A homossexualidade acompanha a história do homem. Não é crime nem pecado; não é uma doença nem um vício. Também não é um mal contagioso, nada justificando a dificuldade que as pessoas têm de ser amigas de homossexuais. É simplesmente outra forma de viver. (...) Mas tanto a orientação homossexual não é uma doença que, na Classificação Internacional das Doenças- CID, está inserida no capítulo Dos Sintomas Decorrentes de Circunstâncias Psicossociais. O termo 'homossexualismo' foi substituido por homossexualidade, pois o sufixo 'ismo' significa 'doença', enquanto o sufixo 'dade’ quer dizer modo de ser.” (DIAS, 2007, 186) 
Por fim, há de se reconhecer que tanto para a CF 88 quanto para o CC a família é um conceito aberto, exatamente para se promover a proteção jurídica de todos os tipos de família não mencionados expressamente na lei. Conforme Roberto Arriada Loreia: "A nova definição de família se harmoniza com o conceito de casamento 'entre cônjuges' do art. 1.511 do CC, não apenas deixando de fazer qualquer alusão à oposição de sexos, mas explicitando que a heterossexualidade não é condição para o casamento, consagrando-a como um direito humano e universal, e não mais um privilégio heterossexual." (DIAS, 2011:41)

O texto constitucional, inclusive, previu expressamente nos parágrafos do art. 226 da CF88, além da família matrimonializada, outros tipos comuns de entidades familiares quando dispõe da união estável ou da família monoparental. Assim, o entendimento é que família é um instituto mais amplo que o casamento, e não é só com este que ela inicia. 


\title{
HOMOSSEXUALIDADE, ESTADO LAICO E IGREJA CATÓLICA
}

\author{
"Os pastores de almas que se opõem ao casamento entre \\ homossexuais têm o direito de recomendar a seus rebanhos \\ que não o façam, mas não podem ser nazistas a ponto de \\ pretender impor sua vontade aos mais esclarecidos."- Drauzio \\ Varella
}

A homossexualidade sempre foi reprovada e rechaçada pela Igreja. Esta considerava pecado no qual a Inquisição castigava com a morte. Para a Igreja Católica $^{7}$, a prática de atos sexuais sem intuito de reprodução, por pessoas do mesmo sexo, sempre foi vista negativamente e considerada como o "pecado da carne". O fato é que a Igreja se preocupa com a conservação da família naturalmente formada e, independentemente de seus motivos, a respeito das uniões homoafetivas e, particularmente, sobre casamento homoafetivo, o seu entendimento oficial é o de reprovação.

\section{Conforme leciona Marianna Chaves:}

"no universo judaico-cristão muitos crêem que a fonte principal de condenação à homossexualidade é a Bíblia, e algumas passagens do Livro Santo têm sido interpretadas como condenatórias destas práticas, de forma, por vezes, equivocada. São habitualmente evocadas dez citações da Bíblia como relativas à homossexualidade. Quatro delas (Deuteronómio 23:17, 1 Reis 14:24, 1 Reis 22:46, e 2 Reis 23:7) proíbem tão somente a prostituição feminina e masculina.. Duas outras referências (Levítico 18:19-23 e Levítico 20:10-16- 'O homem que se deita com outro homem, como se fosse uma mulher, comete uma abominação. Os dois serão réus de morte, e o sangue deles cairá sobre eles mesmos') fazem parte do chamado Código Sagrado, que explicitamente rechaça os atos homossexuais." (CHAVES, 2011: 54)

Com efeito, encontramos nesta ideologia religiosa boa parte da discriminação e intolerância que existe contra as minorias sexuais. Ainda que haja uma grande distância entre as normas morais e éticas estabelecidas

\footnotetext{
${ }^{7}$ Minha análise será feita sob a perspectiva católica pelo fato da instituição PUC seguir tal religião e ser o Brasil o maior país católico do mundo, adotando essa religião como oficial, conforme estatísticas constantes da imprensa nacional.
} 
por uma determinada religião e as que são realmente praticadas por seus fiéis, o fato é que a religião católica não aceita o homossexualismo. A Igreja pretende que a união entre homem e mulher não venha a satisfazer um desejo, a libido do ser humano, mas que venha a promover a procriação: crescei e multiplicai-vos. Assim, os vínculos homossexuais, em razão de sua infertilidade, são relegados à margem da sociedade. E a forma mais simplista de demonstrar reprovação a tudo que desagrada à maioria conservadora religiosa é continuar condenando à invisibilidade. No entanto, a moral cristã não pode influenciar o Estado a ponto de impedir o reconhecimento de direitos aos homossexuais.

Adverte Maria Berenice Dias:

"Cabe lembrar que a Igreja Católica não admite o casamento de pessoas que não tenham capacidade procriativa. Quem for estéril não pode casar. Se houve o casamento, cabe ser anulado. Inclusive, quando o pedido de anulação é a impossibilidade de procriar, é mais fácil desfazer o casamento religioso do que anular o casamento civil." (DIAS, 2007:140)

Neste sentido, pode-se destacar o fato de que, atualmente, a posição da Igreja Católica está bastante antagônica. Isso porque de acordo com as passagens bíblicas, todo e qualquer ato sexual que não possua finalidade procriativa é "antinatural" e condenado por Deus. Contudo, considerando os métodos contraceptivos utilizados por grande parte dos católicos, a discriminação da prática homossexual por tal motivo não faria sentido.

Em uma das manifestações, ainda no tempo do Papa João Paulo II, o Vaticano apresentou uma campanha mundial contra a legalização de uniões homossexuais na qual requisitava aos políticos católicos de todo o mundo que deliberassem contrariamente às leis que as protegessem. Isso porque a Igreja afirmava que reconhecer legalmente as uniões homoafetivas significaria aprovar um comportamento desviado, assim como afetar 
valores fundamentais. Não devemos, no entanto, confundir a questão religiosa com a liderança política.

Isso porque o Estado brasileiro é, conforme definição da CF 88, um Estado laico, nesse sentido são os preceitos do art. $5^{\circ}$, incisos VI e VIII, e do art. 19, inciso I. Estado laico é aquele que não se confunde com determinada religião, permitindo uma ampla liberdade de crença na qual fundamentações religiosas não podem ser usadas como justificativas válidas para fundamentar decisões jurídicas e políticas de uma nação. Em outras palavras, não se pode valer-se de políticos para cumprir os fins sóciopolíticos de grupos religiosos ou, ainda, se utilizar da fé em busca da legitimidade política.

É o que fundamenta com preciosidade Vecchiatti:

"É evidente que o Estado brasileiro não pode utilizar-se de fundamentações religiosas para justificar discriminações políticas $\boldsymbol{e}$ jurídicas, ante a proibição de manutenção de relações de dependência ou aliança com os credos religiosos. Ademais, é uma decorrência lógica do princípio da laicidade estatal essa proibição visto que as religiões baseiam-se em supostas 'verdades universais', que não admitem discussão, por mais que toda racionalidade humana aponte para o sentido contrário. Afinal, as religiões baseiam-se em um ponto que lhes é muito cômodo: a fé não necessita de comprovação - basta que alguma colocação seja professada e que nela se acredite, ante a afirmação que seria baseada na 'palavra de Deus'. Mas, ao contrário, a isonomia exige comprovação lógicocientífico-racional, sendo esta a única forma válida de se criarem discriminações jurídicas, o que significa que, além de violar o princípio do Estado Laico, fundamentar uma discriminação jurídica em explicações religiosas afronta também o princípio da igualdade, que supõe a existência de pelo menos um fundamento lógico-racional que justifique a discriminação pretendida com base no critério discriminador erigido. Ou seja, não se podem usar explicações religiosas para fundamentar diferenciações jurídicas, dada a sua absoluta arbitrariedade: arbitrariedade porque não admitem discussões ou debates. Como são colocadas como 'consagração' da palavra de Deus, os religiosos que as defendem não admitem sequer que alguém as questione. Não é incomum alguém ser chamado de 'herege', 'pecador' e outros nomes afins, por 'ousar' criticar racionalmente os dogmas religiosos." (VECCHIATTI, 2008:132-133)

Sobre Estado laico, mostra-se relevante destacar o entendimento de Roberto Arriada Lorea: 
"O Estado laico não é ateu nem religioso. Não deve perseguir as religiões, nem promover a religiosidade. Tratando-se de estabelecer regras de convivência, deve-se buscar o mínimo de restrição com o máximo de liberdade, sempre focando o respeito à diversidade religiosa, contemplando crentes e não crentes. Em outras palavras, liberdade de expressão religiosa não se confunde com liberdade de opressão religiosa". (LOREA, 2008:132)

Por outro lado, se um juiz, atuando à luz das suas crenças pessoais, decide que o casamento homossexual não pode ser reconhecido pelo fato da Bíblia condenar a homossexualidade, incorreria em violação das liberdades laicas, visto que se vale da posição de Estado-juiz para, através da sentença, impor suas convicções religiosas. Deve-se, portanto, rechaçar a influência religiosa nas decisões judiciais de modo que estas sejam racionalmente fundamentadas e que reconheçam, ainda, que se tal direito é acessível aos heterossexuais, deve igualmente estar disponível à população LGBT. Isso porque vivemos em uma democracia laica e não em uma monarquia religiosa e as pessoas, mesmo contrárias ao casamento homoafetivo, devem obediência ao ordenamento jurídico.

Uma grande confusão que precisa ser superada pela sociedade diz respeito à distinção entre o casamento civil e o sacramento religioso presente em muitas religiões, mas não em todas. De fato, o que se pleiteia neste trabalho é o direito ao casamento civil homoafetivo, e não o religioso. Sobretudo porque a celebração daquele não afronta a liberdade religiosa constitucionalmente consagrada. Isso porque não prejudicará o direito de casais heteroafetivos a igualmente se casarem, bem como não influenciará os mesmos a se casarem com pessoas do mesmo sexo. Assim, tal reconhecimento não obrigaria as religiões que condenam a homossexualidade a celebrarem, ninguém será obrigado a aceitar a homossexualidade dentro de sua fé religiosa. Não haverá, portanto, intromissão na liberdade de crença das religiões, que continuarão a consagrar as uniões amorosas apenas de acordo com seus dogmas. 
Neste aspecto, há outro forte argumento no tocante à proibição da vinculação do direito ao matrimônio à religião: a liberdade religiosa consiste também no direito de não ter sua vida influenciada pela religião alheia. Assim, todos têm a prerrogativa de, se assim escolherem, não terem suas vidas ditadas pela religião. Sobretudo porque a crença religiosa é de cada um, que tem fé no que acredita, mas os direitos civis devem ser concedidos a todos indistintamente.

É o que expõe Paulo Roberto Iotti Vecchiatti:

"É de se reiterar aqui, a lição de Canotillo e de Vital Moreira no sentido de que a liberdade religiosa consiste também no direito de não ter sua vida influenciada pela religião alheia.Nesse sentido interpretação do Direito levaria inexoravelmente à imposição à homossexuais de padrões religiosos com os quais estes não concordam, o que implica necessariamente afronta à sua liberdade religiosa, na medida em que têm estes o direito de não terem suas vidas ditadas pela religião ou interpretação religiosa alheia. Por sua vez, heterossexuais não terão sua liberdade religiosa afrontada pelo reconhecimento da possibilidade jurídica do casamento civil, da união estável e da adoção por casais homoafetivos, porque poderão continuar se casando apenas com pessoas do sexo diverso e em nada serão afetados por ditos reconhecimentos. Assim, este é mais um fundamento que comprova a impossibilidade de utilização de fundamentações religiosas na interpretação do Direito, sendo a religião completamente irrelevante neste sentido." (VECCHIATTI, 2008:412-413)

O Estado laico, por outro lado, não deve ser interpretado como uma instituição anti-religiosa até porque foi ele mesmo o garantidor das liberdades religiosas. Deve-se recordar que a liberdade de crenças, a liberdade de culto e a tolerância religiosa foram asseguradas graças ao Estado laico, e não como oposição a ele. Isso porque não se pode reconhecer um regime de liberdade religiosa, sem a garantia da laicidade estatal.

Nesse sentido pode-se citar a afirmação de Roberto Arriada Lorea: "Essa confusão fica evidente na fala 'O Estado pode ser laico mas a população não é”, pois se parte da premissa de que ou se é religioso ou laico, como se fossem posturas excludentes. De fato, não há contradição 
em ser religioso e laico. Para tanto, basta que se respeite igual liberdade de crença ao outro.” (LOREA, 2007:38)

Para Daniel Helminiak, parece que os homossexuais (católicos) devem optar entre desistir de sua religião ou - o que parece impossível desistir de sua sexualidade. (HELMINIAK, 1998:20) De fato, o que em realidade ocorre é que nossos legisladores e operadores do direito são, em sua maioria, conservadores e afetados pela opinião da igreja, o que provoca o atraso do nosso ordenamento em regular a questão fática da união entre homossexuais. A laicidade deveria, no entanto, possibilitar a convivência de variadas formas de compreensão do mundo, o que supõe zelo pelo interesse público através de normas, princípios e valores jurídicos que reflitam o respeito à proteção dos direitos das minorias, nesse particular os direitos das minorias sexuais.

Para encerrar o presente capítulo, destaco o texto da renomada autora Martha Medeiros:

\section{$\underline{\text { A fé de uns e de outros }}$}

"Religião deveria servir apenas para promover o amor e a paz de espírito. Apoio que as pessoas se manifestem publicamente contra a violência urbana, contra os altos impostos que não são revertidos em benefícios sociais, contra a corrupção, contra a injustiça, contra o descaso com o meio ambiente, enfim, contra tudo o que prejudica o desenvolvimento da sociedade e o bem-estar pessoal de cada um. No entanto, tenho dificuldade de entender a mobilização, geralmente furiosa, contra escolhas particulares que não afetam em nada a vida de ninguém, a não ser aos diretamente envolvidos, caso da legalização do casamento gay, que acaba de ser aprovado na Argentina.

Se dois homens ou duas mulheres desejam viver amparados por todos os direitos civis que um casal hétero dispõe, em que isso atrapalha a minha vida ou a sua? Estarão eles matando, roubando, praticando algum crime? No caso de poderem adotar crianças, seria mais saudável elas serem criadas em orfanatos do que num lar afetivo? Ou será que se está temendo que a legalização seja um estímulo para os indecisos? Ora, a homossexualidade faz parte da natureza humana, não é um passatempo, um modismo. É um fato: algumas pessoas se sentem atraídas - e se apaixonam - por parceiros do mesmo sexo. Acontece desde que o mundo é mundo. E se por acaso um filho ou neto 
nosso tiver essa mesma inclinação, é preferível que ele cresça numa sociedade que não o estigmatize. Ou é lenda que queremos o melhor para nossos filhos?

No entanto, o que a mim parece lógico, não passa de um pântano para grande parcela da sociedade, principalmente para os católicos praticantes. Entendo e respeito o incômodo que sentem com a situação, que é contrária às diretrizes do Senhor, mas na minha santa inocência, ainda acredito que religião deveria servir apenas para promover o amor e a paz de espírito. Se for para promover a culpa e decretar que quem é diferente deve arder no fogo do inferno, então que conforto é esse que a religião promete? Não quero a vida eterna ao custo de subjugar quem nunca me fez mal. Prefiro vida com prazo delimitado, porém vivida em harmonia.

Sei que sou uma desastrada em tocar num assunto que deixa meio mundo alterado. Daqui a cinco minutos minha caixa de e-mails estará lotada de agressões, mas me concedam o direito ao idealismo, que estou tentando transmitir com a maior doçura possivel: não há nada que faça com que a homossexualidade desapareça como um passe de mágica, ela é inerente a diversos seres humanos e um dia será aceita sem tanto conflito. Só por cima do seu cadáver? Será por cima do cadáver de todos nós, tenha certeza. Claro que ninguém precisa ser conivente com o que lhe choca, mas é mais produtivo batalhar pela erradicação do que torna nossa vida ruim, do que se sentir ameaçado por um preconceito, que é algo tão abstrato.

Pode rir, mas às vezes acho que acredito mais em Deus do que muito cristão."

-Martha Medeiros- 


\title{
PROTEÇÃO CONSTITUCIONAL DA HOMOSSEXUALIDADE
}

\author{
"Anda tão unido o meu tormento comigo que eu mesmo \\ sou meu perigo"- Luis Vaz de Camões
}

Será que o fato de um indivíduo possuir orientação afetiva exclusiva ou preponderantemente homossexual, lhe impediria o pleno exercício da cidadania? Quê mal faz à sociedade o fato de homossexuais poderem ter um relacionamento protegido pela lei civil?? Há algum bem jurídico tutelado que justificasse tal proibição???

A resposta para tais indagações é encontrada, dentre outras áreas de conhecimento, na Constituição Federal. Os princípios constitucionais, explícitos e implícitos, indicam o ponto de partida do legislador e possuem um papel fundamental no amparo dos homossexuais. Quando utilizados em conjunto, possuem uma força de proteção imensurável. Ademais, se a Carta Magna elenca princípios como normas jurídicas de eficácia plena, principalmente na qualidade de direitos humanos fundamentais, toda leitura infraconstitucional e constitucional deve ser feita com base neles, ainda que seja necessária a analogia ou a interpretação extensiva para tanto. Isso nada mais é do que a chamada interpretação conforme a Constituição.

Nestas condições, se o Constituinte elencou princípios mandamentais que vedam o preconceito, como a isonomia e a dignidade da pessoa humana, não podem os demais textos normativos serem valorados pelo dito preconceito, o que afrontaria a devida interpretação sistemática. Sobretudo porque tais mandamentos, que devem ser utilizados como paradigma na interpretação das normas, demonstram a sua finalidade primordial, qual seja, a proibição de discriminações arbitrárias. Nestas circunstâncias e conforme será demonstrado, mostra-se plenamente viável a extensão dos regimes jurídicos do casamento civil aos casais homoafetivos. 
Não se pode afirmar que os dispositivos que utilizam a expressão "homem" e "mulher" estariam "vedando implicitamente" as uniões homoafetivas, uma vez que, se assim considerar-se, estaria configurada a discriminação preconceituosa, vedada constitucionalmente pelos princípios da isonomia e dignidade humana. Como conclui Vecchiatii: "A partir do momento em que é possível interpretar-se uma norma jurídica de duas formas e uma delas é inconstitucional, é obrigatória a utilização da outra, para evitar um conflito entre ditos dispositivos normativos". (VECCHIATTI, 2008:368)

Dessa forma, os dispositivos legais e constitucionais que versem sobre a família, o casamento civil e a união estável, só podem ser interpretados de uma maneira que não proíba o reconhecimento jurídico das uniões homoafetivas, até porque não há proibição no ordenamento jurídico de forma expressa, lembrando-se que inexistem "proibições implícitas" em Direito (art $5^{\circ}$, II da CF88). E considerando que a união homoafetiva possui o mesmo elemento valorativamente protegido que enseja a regulamentação da união heteroafetiva, a saber, o amor familiar, a interpretação conforme a Constituição exige que seja aplicada a analogia ou a interpretação extensiva, a fim de que tais regimes jurídicos sejam disponibilizados às uniões amorosas entre pessoas do mesmo sexo.

Há de se ressaltar que tal método interpretativo não ofende a literalidade dos textos normativos. Isso porque estes se limitam a regular aspectos das uniões heteroafetivas sem, no entanto, proibir a extensão às uniões homoafetivas. Por outro lado, não há proteção de fatos isoladamente considerados, mas de um mesmo valor, que é o amor familiar. É o que defende Vecchiatti: 
'Tal interpretação não ultrapassa o proclamado limite da 'literalidade' dos referidos textos normativos. (i) primeiramente porque a literalidade destes textos normativos realmente se limita a normatizar aspectos das uniões heteroafetivas sem, em nenhum momento, proibir a extensão dos regimes jurídicos do casamento civil e da união estável às uniões homoafetivas; (ii) ademais, os textos normativos não protegem fatos isoladamente considerados, mas valores a eles inerentes, donde se uma situação fática não citada pelo texto normativo possuir o mesmo elemento essencial, valorativamente protegido, que se visou regulamentação na regulação fática expressamente citada pelo mesmo, então a Interpretação conforma a Constituição, demandará pela aplicação da interpretação extensiva ou da analogia para que o fato não regulamentado receba o mesmo tratamento jurídico daquele outro expressamente regulamentado, em virtude de ambos possuírem o mesmo elemento que ensejou a proteção normativa em questão, que é o amor familiar." (VECCHIATTI, 2008:370-371)

Em resumo, as normas jurídicas não protegem apenas situações

fáticas visto que se incluem nelas determinados valores. Assim, o fato de o texto normativo ser omisso em relação à condição dos homossexuais, não implica, necessariamente, que dita situação não possa usufruir do regime jurídico empregado à outra expressamente protegida, quando estão compreendidas, em ambas, os mesmos valores a serem resguardados. Sobretudo porque o tratamento isonômico é a regra, cabendo aos que pretendem discriminar por motivos de orientação sexual o dever de provar a sua pertinência lógico-jurídica.

Dispõe Vecchiatti:

"O que deve ser levado em conta nesse ponto é o fato de existir ou não o mesmo valor protegido pela norma na situação não regulamentada, hipótese na qual será cabível a extensão daquele regime jurídico a esta, seja por meio de interpretação extensiva ou analogia, que são princípios gerais de Direito oriundos do aspecto material da isonomia, no sentido de garantirem o mesmo tratamento jurídico aos iguais (interpretação extensiva) e aos fundamentalmente iguais (analogia).Essa é a exteriorização da interpretação teleológica, que se baseia no objeto de proteção da norma (em sua finalidade), e não segundo a letra fria e eventualmente desatualizada do texto normativo." (grifei) (VECCHIATTI, 2008:143)

Pelo disposto no primeiro capítulo, em nosso ordenamento é incontestável que a possibilidade do direito ao casamento depende de um 
requisito: a orientação sexual. Tal circunstância afronta, integralmente, o princípio da igualdade constitucional. Isso porque o Estado brasileiro trata os cidadãos de forma diversa sem que o referencial para tanto esteja baseado em uma razão lógica e razoável.

Sobre discriminação justificada dispõe Celso Antonio Bandeira de Mello:

"Uma discriminação juridicamente válida é aquela que tiver como objeto pessoas indeterminadas e indetermináveis no momento da elaboração do texto normativo em questão; seja uma decorrência lógico-racional do critério discriminador erigido, ou seja, deverá ser uma decorrência silogística (aspecto lógico) do critério de desigualação eleito e, por mais silogística que seja, deverá ser motivada com fundamentos fático-científicos que a justifiquem (aspecto racional); e, por fim, por maiores que sejam a lógica e a racionalidade que a embasem, seja coerente com os valores constitucionalmente consagrados" (MELLO, 2003:184)

Assim, ainda que o texto normativo constitucional não faça referência expressa à situação fática dos homossexuais, é consagrado expressamente no ordenamento jurídico o princípio da igualdade formal, enunciado no artigo $5^{\circ}$, caput, da CF 88 . Este consagra o direito de todos à igual proteção da lei, conduzindo à garantia do direito às diferenças e ao respeito à diversidade. Neste caso, seriam juridicamente indiferentes as diversas modalidades de orientação sexual, devendo receber, pois, a mesma regulamentação.

$\mathrm{O}$ artigo $3^{\circ}$ inciso IV, da CF88, estabelece, ainda, o rol de critérios proibidos de diferenciação por motivo de origem, raça, sexo, cor, idade e quaisquer outras formas de discriminação. Com efeito, por mais que a expressão "orientação sexual” esteja ausente no rol de expressa proibição, nota-se que a enumeração constitucional convive com a abertura de quaisquer outras formas de discriminação, de onde se extrai do princípio da não discriminação em razão do sexo. Isso porque a parte final de tal 
artigo prevê a proibição de "quaisquer outras formas de discriminação além das elencadas".

Sobre este aspecto, um exemplo que ilustra com clareza de que forma a discriminação por orientação sexual retrata uma hipótese de discriminação por motivo de sexo é o trazido por Roger Raupp Rios:

"Pedro sofrerá ou não discriminação por orientação sexual precisamente em virtude do sexo da pessoa para quem dirigir o seu desejo ou a sua conduta sexual. Se orientar-se para Paulo, experimentará a discriminação. Se dirigir-se para Maria, não suportará tal diferenciação. Os diferentes tratamentos, neste contexto, têm sua razão de ser no sexo de Paulo (igual ao de Pedro) ou de Maria (oposto ao de Pedro)." (RIOS, 2002:132)

É necessário reconhecer, igualmente, o direito ao livre exercício da orientação sexual homossexual como um corolário do princípio da liberdade, assegurado constitucionalmente. Ou seja, o princípio da não discriminação por orientação sexual é nada mais do que a materialização do princípio da igualdade. Isso porque toda e qualquer pessoa possui a prerrogativa de escolher o seu par, independentemente do sexo, bem como a forma de entidade familiar que deseja ser formada. Liberdade consiste, cada vez mais, na ideia de poder realizar, sem intervenção alheia, as próprias escolhas individuais, o próprio projeto de vida.

\section{Para Marianna Chaves:}

"O principio da liberdade se faz presente no sentido de que toda e qualquer pessoa possui prerrogativa de escolher o seu par, independentemente do sexo, assim como o tipo de entidade familiar que deseja constituir. Nas palavras de Maria Berenice: 'em face do primado da liberdade, é assegurado o direito de constituir uma relação conjugal, uma união estável hetero ou homossexual. Há a liberdade de extinguir ou dissolver o casamento e a união estável, bem como o direito de recompor novas estruturas de convivio.' Ao se desdobrar os direitos em gerações, é de se afirmar que a sexualidade é um direito de primeira geração, da mesma forma que a igualdade e a liberdade, pois engloba o direito à liberdade sexual, aliado ao tratamento isonômico, independentemente da orientação sexual, é, destarte, uma liberdade individual, um direito da pessoa humana, sendo, como todos os direitos de primeira geração, imprescritivel e 
inalienável. Trata-se de um direito natural, que acompanha o indivíduo desde o nascimento " (CHAVES, 2011:73)

Tal princípio, da mesma forma quando direcionado às relações heteroafetivas, deve ser aplicado, também, quando da formação, manutenção e extinção dos arranjos familiares homoafetivos. Isso porque se o conceito e a forma de constituir família mudaram, não há mais motivos para que ao Estado interesse regular assuntos que limitem, profundamente, a liberdade dos indivíduos quando não existem repercussão e interesse público para tanto. Este último valor, por sua vez, pode ser traduzido no livre poder de escolha ou autonomia no ato de constituir, realizar ou extinguir entidade familiar, sem coerção ou imiscuição de parentes, da sociedade ou do próprio legislador. (CHAVES, 2011:72)

Assim, a orientação sexual do indivíduo, sendo inserida na esfera de sua privacidade e personalidade, não admite restrições. No entanto, no estágio atual, as relações homoafetivas ainda se sujeitam à deficiência de regulação jurídica, sendo deixadas à margem da sociedade. Porém, qualquer limitação estaria indo contra a máxima da liberdade, do livre desenvolvimento de sua personalidade e da realização de felicidade pessoal, elementos inerentes com a condição de vida.

Como bem afirma Rodrigo da Cunha Pereira:

"a verdadeira liberdade e o ideal de Justiça estão naqueles ordenamentos jurídicos que asseguram um Direito de Família que compreenda a essência da vida: dar e receber amor. A liberdade consiste, afinal, na possibilidade de uma coordenação consciente dos meios necessários ao desenvolvimento da personalidade e à realização da felicidade pessoal." (PEREIRA, 2003b:161)

O princípio elencado no artigo $1^{\circ}$ inciso III da CF 88 , por sua vez, ao definir a dignidade da pessoa humana como um dos fundamentos da República, visa proteger o ser humano do próprio ser humano. Isso significa que aqueles em melhores condições fáticas não podem se aproveitar disso para subjugar outros, em pior situação. Há, portanto, uma superação 
patrimonialista ensejada pelos valores que efetivamente trazem felicidade às pessoas: o amor, o respeito recíproco, a solidariedade entre outros. Trata-se, na verdade, do direito à felicidade "na medida em que a realidade empírica demonstra que a própria existência humana destina-se a evitar o sofrimento e a buscar aquilo que acreditamos que nos trará felicidade." (VECCHIATTI, 2008:159)

Assim, tal princípio, que deve ser considerado a base dos ordenamentos jurídicos modernos, garante o direito de busca à felicidade aos indivíduos, desde que outras pessoas não sejam prejudicadas nesse processo. Portanto, todos os cidadãos, simplesmente pelo fato de serem pessoas humanas, são merecedores da garantia da mesma dignidade pelo ordenamento jurídico.

\begin{abstract}
Assevera Rodrigo da Cunha Pereira que
"a dignidade é um macroprincípio sob o qual irradiam e estão contidos outros princípios e valores essenciais como a liberdade, autonomia privada, cidadania, igualdade, alteridade e solidariedade. São, portanto, uma coleção de princípios éticos. (...) Essas inscrições são resultado e conseqüência de lutas e conquistas políticas associadas à evolução do pensamento, desenvolvimento das ciências e novas tecnologias. É a noção de dignidade e indignidade que possibilitou pensar, organizar e desenvolver os direitos humanos." (PEREIRA, 2003a:94)
\end{abstract}

Neste sentido, o ministro Celso Mello, em seu voto na recente decisão do $\mathrm{STF}^{8}$ :

\begin{abstract}
"O postulado constitucional da busca da felicidade, que decorre, por implicitude, do núcleo de que se irradia o princípio da dignidade da pessoa humana, assume papel de extremo relevo no processo de afirmação, gozo e expansão dos direitos fundamentais, qualificando-se, em função de sua própria teleologia, como fator de neutralização de práticas ou de omissões lesivas cuja ocorrência possa comprometer, afetar ou, até mesmo, esterilizar direitos $\boldsymbol{e}$ franquias individuais."
\end{abstract}

\footnotetext{
${ }^{8}$ STF, ADI 4277 e ADPF 132- RJ, julgamento conjunto em 04 e 05 de maio de 2011, Relator: Ministro Ayres Britto.
} 
Desta forma, reconhecido o papel crucial que a expressão sexual e emocional possui para o bem-estar e realização existencial dos indivíduos, o princípio da dignidade da pessoa humana, ainda que implicitamente, visa a permitir e proteger todas as formas de orientação sexual na medida em que também proíbe qualquer tipo de distinção entre os cidadãos do país (art $5^{\circ}$ da CF 88).

Para Cristiano Chaves de Farias:

\begin{abstract}
"abandona-se o casamento como ponto referencial necessário, para buscar a proteção e o desenvolvimento da personalidade do homem. É a busca da dignidade humana sobrepujando valores meramente patrimoniais. Considerando o acatamento do princípio da dignidade humana como valor fundante de todo ordenamento jurídico, sobreleva a elevação do ser humano ao centro de todo o sistema jurídico, no sentido de que as normas são feitas para a pessoa e sua realização existencial, devendo garantir-lhe um mínimo de direitos fundamentais que sejam vocacionados para the proporcionar vida com dignidade. Ora, a afirmação dessa fundamentalidade do princípio da dignidade da pessoa humana impõe uma nova postura aos civilistas pós-modernos, que devem, na interpretação e aplicação das normas e conceitos jurídicos prosseguir na luta incansável contra tudo que ameace a completa integridade humana." (FARIAS, 2007: 132-133)
\end{abstract}

\title{
Já Marianna Chaves. . .
}

\begin{abstract}
"A dignidade da pessoa humana não constitui uma criação constitucional, tendo em vista que se trata de um dado preexistente a toda tentativa especulativa, assim como a própria pessoa humana. (...) Para aclarar o significado da dignidade da pessoa humana como fundamento da República, assevera a doutrina portuguesa que se trata do reconhecimento do indivíduo como limite e fundamento do domínio político da República, em virtude de ocorrências históricas de tentativa de extermínio do ser humano, tais como: genocídios étnicos, escravatura, inquisição, nazismos, entre outras. A noção de dignidade da pessoa humana abrange o núcleo existencial que é essencialmente comum a todos os seres do gênero humano. Impõe-se, no que tange à dimensão pessoal da dignidade, um dever geral de respeito, proteção e intocabilidade, seno inadmissivel qualquer procedimento, comportamento ou atividade que 'coisifique' o individuo" (CHAVES, 2011:67-68)
\end{abstract}

Assim, na estruturação da individualidade de qualquer pessoa, a sexualidade se revela como uma das formas do desenvolvimento de sua personalidade. Portanto, o amparo da dignidade da pessoa se relaciona diretamente com as questões concernentes à sexualidade e sua orientação. 
Sendo esta uma condição essencial para sua identidade, não pode, em nenhuma hipótese, ser ignorada ou rechaçada sob pena de violação direta ao princípio da dignidade da pessoa humana.

A respeito dessa restrição de direitos às minorias sexuais, indaga Vecchiatti:

\begin{abstract}
"pode a maioria da população restringir os direitos das minorias? (...) Depende. Se essa mesma população consagrou em sua Constituição (ou em seu ordenamento jurídico em geral) princípios jurídicos que vedam a discriminação arbitrária (isonomia) e que colocam todas as pessoas humanas em igual grau de dignidade (dignidade da pessoa humana), como é o caso brasileiro, então a resposta é não. (...) Mesmo que a esmagadora maioria da população queira que os homossexuais tenham menos direitos que os heterossexuais, tal é incompativel com os citados ordenamentos jurídicos que consagram os princípios da isonomia e da dignidade da pessoa humana (que vedam qualquer discriminação arbitrária como essa) como direitos humanos fundamentais, não podendo, portanto, tal vontade majoritária, se algum dia vier a existir, prevalecer. (...) Isso serve de resposta àqueles que tanto desejam colocar em votação popular, por meio de plebiscito, a questão da regulamentação das uniões homoafetivas. (...) Direitos fundamentais não podem ser colocados em votação; devem ser conferidos a todos os brasileiros, ponto. (...) Em especial, será inconstitucional um plebiscito que dê à maioria o direito de decidir sobre algo que afeta unicamente a minoria: ora, uma lei de "união civil homoafetiva" só será relevante para homossexuais e bissexuais, não tendo heterossexuais nenhum legitimo interesse nesse tema, visto que não serão atingidos nem abarcados por tal lei." (VECCHIATTI, 2008:22529):
\end{abstract}

Pelo princípio da afetividade percebemos a desbiologização do Direito de Família. O afeto passa a ser considerado um valor jurídico na medida em que relações são consideradas familiares quando da presença de tal elemento anímico, sendo indiferente o vínculo sanguíneo. Desta forma, fazendo-se uma correlação entre os princípios da liberdade, o da nãodiscriminação - seja por razão do sexo ou orientação sexual-, e o da igualdade, pode inferir-se que as uniões homoafetivas também estão sob o manto protetor do princípio da afetividade.

"Note-se que, em virtude do disposto no art 1511 do CC brasileiro", a tônica do vínculo matrimonial gira em torno do afeto (plena comunhão de vida). Com mais

\footnotetext{
${ }^{9}$ Art 1.511 do CC: "O casamento estabelece comunhão de plena vida, com base na igualdade de direitos e deveres dos cônjuges."
} 
propriedade ainda, é de se afirmar que a affectio é o núcleo caracterizador das relações entre companheiros, especialmente por força da informalidade do vínculo jurídico existente entre eles. Assim, parece arrazoada a ideia de que a afetividade também é princípio infraconstitucional que norteia os vínculos amorosos entre pessoas do mesmo sexo, uma vez que tais relações, em sua essência, são iguais às ligações heterossexuais." (CHAVES, 2011:78)

Nestas condições, não existem modelos únicos ou preferenciais. De fato, o que caracteriza e integra tais núcleos familiares é a existência da afetividade. Na concepção de Vecchiatti:

\begin{abstract}
“(...) mudou-se o paradigma da família: de uma entidade fechada dentro de si, válida por si mesma, passou a existir somente em função do amor entre os cônjuges/companheiros, tendo em vista que a sociedade passou a dar mais relevância à felicidade, portanto à afetividade amorosa, do que à mera formalidade do casamento civil ou a qualquer outra forma preconcebida de família. Nesse sentido, o reconhecimento do 'status' jurídico-familiar da união estável, por si, alçou o afeto à condição de princípio jurídico implícito, na medida em que é ele, afeto (amor romântico, no caso), o motivo que faz com que duas pessoas decidam manter uma união estável. O elemento formador da família contemporânea é o 'amor familiar', mas é o amor romântico que dá o passo inicial para a constituição da união estável, embora haja outros argumentos a corroborar a afirmação de que o afeto é um princípio jurídico. (...) Com efeito, a partir do momento em que a Constituição Federal reconheceu o amor como o principal elemento formador da entidade familiar nãomatrimonializada, alçou a afetividade amorosa à condição de princípio constitucional implícito, que pode ser extraído em função do art. $5 .^{\circ}, \S 2 .^{\circ}$, da CF/1988, que permite o reconhecimento de princípios implícitos por decorrentes dos demais princípios $\boldsymbol{e}$ do sistema constitucional (além dos tratados internacionais de direitos humanos dos quais o Brasil faça parte). Essa evolução social quanto à compreensão da família elevou o afeto à condição de princípio jurídico oriundo da dignidade da pessoa humana no que tange às relações familiares, visto que estas, para garantirem o direito à felicidade e a uma vida digna (inerentes à dignidade humana), precisam ser pautadas pelo afeto e não por meras formalidades como a do casamento civil. Assim, 'o princípio do afeto é um princípio constitucional implícito, decorrente da dignidade da pessoa humana e, ainda, da própria união estável', que tem, nele, o principal elemento para reconhecimento do 'status' jurídico-familiar de uniões não matrimonializadas." (VECCHIATTI, 2008:220-221)
\end{abstract}

Diante, também, da interpretação constitucional e da aplicação do princípio da pluralidade de formas familiares, é imprescindível que seja tutelado todo o grupo que, pelo vínculo afetivo, se apresente como família. Tal princípio deve ser vislumbrado, portanto, como o reconhecimento estatal da existência de várias possibilidades de arranjos familiares, entre os quais se apresenta a família homoafetiva. Nestas circunstâncias, a 
importância deste princípio, conforme demonstrado no primeiro capítulo, reside na legitimação e desmarginalização dos laços que já podem ser considerados familiares em razão da presença do afeto.

"O princípio da pluralidade familiar se desdobra no princípio da igualdade das entidades e no de materialização do princípio da dignidade da pessoa humana. Como adverte Paulo Lôbo: 'consulta a dignidade da pessoa humana a liberdade de escolher e constituir a entidade familiar que melhor corresponda à sua dignidade existencial. Não pode o legislador definir qual a melhor e a mais adequada.' Destarte, a liberdade do núcleo familiar deve ser vislumbrada como liberdade do indivíduo de constituir família de acordo com sua própria opção e como liberdade de nela desenvolver a sua personalidade." (LÔBO, 2008:59)

Para Vecchiatti, o princípio da proporcionalidade seria uma forma de controle de atos públicos a fim de invalidar aqueles que se mostrem inaptos a obter a finalidade por eles pretendida ou que sejam mais gravosos do que outros possíveis para o mesmo fim:

\begin{abstract}
"Oriundo inicialmente de construção jurisprudencial do Tribunal Constitucional Alemão, o princípio da proporcionalidade visa, precipuamente, servir como método de controle dos atos estatais no sentido averiguar a adequação, necessidade e a proporcionalidade em sentido estrito das medidas estatais em debate para, neste terceiro momento, solucionar o conflito entre dois ou mais direitos fundamentais em choque por parte dessas medidas, por meio de um juízo de ponderação entre os mesmos para, identificando aquele que seria mais relevante no caso concreto, sacrificar-se (o menos possível) o outro.(...) Tal princípio é subdividido em três subprincípios a ele inerentes: o da adequação, necessidade e proporcionalidade em sentido estrito. A adequação significa que a medida impugnada deve ser apta a atingir o fim por ela pretendido; a necessidade aponta que deve ser utilizado o meio menos gravoso para atingir aquele fim; por fim, a proporcionalidade em sentido estrito significa que o que se ganha com a restrição deve ser maior do que o que ser perde com ela, o que se verifica por meio de uma ponderação entre os direitos em conflito para apurar qual deles deverá ser sacrificado, por ser menos relevante, ou qual a forma de compatibilização entre eles para evitar o conflito efetivo e acabar com a tensão existente (...)É de se notar que somente haverá respeito à isonomia na diferenciação se esta for: adequada para atingir os fins pretendidos, necessária ante a inexistência de outra forma menos gravosa para tanto; e, por fim, proporcional em sentido estrito, no sentido de que o valor protegido com a desequiparação deve ser maior do que o valor sacrificado por ela no caso concreto. Apenas assim a discriminação será proporcional e, consequentemente, válida" (VECCHIATTI, 2008:140-144)
\end{abstract}

No entanto, para Maria Berenice Dias, a interpretação a ser dada a tal princípio deve ser outra. Isso porque seria o princípio da razoabilidade o 
voltado à aferição de constitucionalidade de atos emanados do Poder Público, vedando o excesso e arbitrariedade enquanto que a proporcionalidade:

\footnotetext{
"se destinaria à manutenção e conformação da coexistência pacífica $e$ harmoniosa do amplo rol de direitos fundamentais consagrados à pessoa humana. (...) Sempre que o embate entre direitos fundamentais for inevitável, a proporcionalidade deverá ser utilizada como critério de ponderação para evitar que qualquer dos direitos fundamentais em conflito seja totalmente desprezado, o que lhe retiraria a caracteristica fundamental." (DIAS, 2011:189)
}

Assim, na luta pelo reconhecimento dos direitos homoafetivos o princípio da proporcionalidade não seria essencial pelo fato de que o reconhecimento de tais direitos não importa em qualquer colisão com outro direito fundamental. Nas palavras de Luís Roberto Barroso: "Cuida-se, aqui, de uma verificação entre os danos causados e os resultados a serem obtidos”. (BARROSO, 2006:228)

A homoafetividade é também protegida pela inviolabilidade da intimidade e da vida privada (art. $5^{\circ}$, inciso $\mathrm{X}$, da CF88) e da liberdade de consciência (art. $5^{\circ}$, inciso VI, da CF88). De outro modo, pelo preceito constitucional segundo o qual ninguém será obrigado a fazer ou deixar de fazer alguma coisa senão em virtude de lei (art. 5ª inciso III), a homossexualidade constitui um irrelevante jurídico, posto não ser ela proibida por lei. Muito pelo contrário, a CF 88 garante a livre orientação sexual e afetiva, o que inclui-se, como uma de suas formas, a homossexualidade.

Ressalte-se, também, conforme destacado em capítulo próprio do presente trabalho, nenhum motivo de ordem religiosa serve para fundamentar uma discriminação ainda que juridicamente válida. Isso porque o Brasil é um Estado Laico, no qual religião não pode influir no ordenamento jurídico pátrio pois, do contrário, haveria uma relação de 
aliança com a religião em questão, o que é expressamente vedado pelo artigo 19, I, da CF 88, ferindo, assim, o princípio da laicidade.

Assim, diante todo o exposto, é de se compreender que quando a legislação não conferir tratamento jurídico a determinada entidade familiar, esta deve ser norteada pelos princípios constitucionais, ainda que implícitos, bem como pelas regras do Direito das Famílias. Isso porque a relevância maior não se encontra na concepção da união homossexual em legislação infraconstitucional. Não se pretende defender tão somente a necessidade de uma tipificação detalhada da lei sobre a união entre pessoas do mesmo sexo. O enfoque, na construção da defesa dos efeitos jurídicos às parcerias homossexuais, encontra-se, principalmente, nos valores existenciais atualmente inseridos constitucionalmente como princípios e direitos fundamentais em nossa Constituição Federal. 


\section{CASAMENTO CIVIL HOMOAFETIVO}

"Se todos conhecessem a intimidade sexual uns dos outros, ninguém cumprimentaria ninguém.”-Nelson Rodrigues

O direito ao casamento se relaciona de forma direta com o exercício de diversos direitos fundamentais, como o direito à liberdade, à igualdade, à intimidade, assim como o direito ao livre desenvolvimento da personalidade, todos eles derivados da dignidade da pessoa humana. Em realidade, o casamento é um compromisso moral, fortalecido pelo companheirismo com amparo mútuo e que não deve ser limitado às pessoas de sexo diferente. A não extensão do direito das famílias para a proteção das uniões homoafetivas constitui uma injusta discriminação jurídica visto que tais uniões não são mera sociedade de fato e não podem se contentar apenas com o reconhecimento recente de "união estável", ainda que já seja um grande avanço. Isso porque em tais relações se verifica o elemento formador da família moderna: o afeto.

Não há como aceitar motivos para a manutenção do monopólio do casamento heterossexual. Os argumentos contrários invocam que homossexuais não cumprem com os deveres sociais do casamento, como continuação da espécie, educação dos filhos e transmissão de valores culturais. Alegam, também, que mulher "domestica" o homem, fazendo o casamento funcionar e que o matrimônio gay enfraqueceria o próprio instituto do casamento. Uma aberração. Enfatizam, ainda, que a regra de ser celebrado entre pessoas de sexo diferente não é arbitrária por existirem razões de ordem sociológica, histórica, demográfica e de bem comum que a justificam.

"quando os homossexuais evidenciam que a proibição ao casamento está a prejudicá-los legalmente, economicamente e emocionalmente, a sociedade é obrigada a explicar a razão pela qual este aspecto particular do casamento heterossexualidade obrigatória- deve permanecer inalterado, quantos tantos outros aspectos mudaram drasticamente Uma justificação consistente parece inexistir. $O$ que emerge por todos os lados são argumentos débeis e facilmente ultrapassáveis. "'(CHAVES,2011:204) 
Primeiramente, há de se dizer que constituir família não implica, necessariamente, em ter descendentes. A capacidade procriativa ou a intenção de ter filhos não é condição elencada pela legislação para constituir família. Se assim fosse, não poderiam ser reconhecidas como famílias as formadas por casais heteroafetivos estéreis, ou o casamento contraído por mulher que já estivesse na meno pausa ou, ainda, daqueles que simplesmente não quisessem ter filhos.

É o que dispõe claramente Marianna Chaves:

"Merece especial atenção o argumento da supra referido da continuação da espécie como dever social do casamento. Note-se que é idéia arraigada na doutrina mundial que a procriação não constitui escopo do casamento. Se assim o fosse, casamento entre pessoas idosas ou entre pessoas inférteis seria vedado. Do mesmo modo, não existe óbice algum ao casamento entre parceiros férteis que não desejem ter filhos, mas querem desfrutar dos benefícios e direitos oriundos da relação matrimonializada. Na atualidade social, os conceitos de casamento e família não mais se confundem. Já não existe base para qualquer postulado de conexão entre família e casamento. É sabido que o reconhecimento legal de uma família não se encontra mais restrito na lógica do casamento plus crianças. Existem pluri ou multiformas de se constituir família. E para se formar uma família, não se faz necessária a presença de prole, como já foi referido." (CHAVES, 2011:198)

Contudo, alguns teóricos ainda não reconhecem a possibilidade jurídica de homoafetivos constituírem uma família por lhes faltar tal capacidade procriativa natural. Considerando os art. 1.511, 1.566 e 1.723 do CC, enfatiza-se, mais uma vez, que a capacidade reprodutora não é requisito para constituição de família. De fato, o que importa é a conjugação do amor a uma comunhão plena de vida e interesses de forma pública, contínua e duradoura, com as consequiências que esta acarreta, a mútua assistência, a vida em comum, o respeito e consideração mútuos, o que pode ocorrer tanto em casais heteroafetivos ou homoafetivos. Do contrário configurar-se-ia puro preconceito segregacionista.

No entanto, com base na redação do artigo 226 parágrafo $3^{\circ}$ da $\mathrm{CF}$ 88: "Para efeito da proteção do Estado, é reconhecida a união estável entre o homem e a mulher como entidade familiar, devendo a lei facilitar a sua conversão em casamento", muitos defendem que a Constituição teria 
limitado a união estável apenas a casais formados por pessoas de sexos diversos, por ser supostamente "clara" a referência neste sentido. Contudo, essa não é essa a interpretação a ser feita.

Tal expressão não constitui uma "proibição implícita" ao reconhecimento da união estável ou casamento homoafetivo, tendo em vista que não há proibições implícitas em nosso ordenamento jurídico e a norma em questão sequer declina sobre questões homoafetivas. Trata-se de uma norma de inclusão no âmbito de proteção do direito das famílias de estruturas familiares não matrimonializadas, não se prestando a exclusão de outras maneiras de organização familiar. Da mesma forma, o CC não condicionou o casamento à necessária diversidade de sexo dos nubentes. Os seus dispositivos legais em que constam "homem e mulher" não dizem respeito à exclusividade entre homem e mulher:

"Art. 1.514. O casamento se realiza no momento em que o homem e a mulher manifestam, perante o juiz, a sua vontade de estabelecer vínculo conjugal, e o juiz os declara casados."

"Art. 1.517. O homem e a mulher com dezesseis anos podem casar, exigindo-se autorização de ambos os pais, ou de seus representantes legais, enquanto não atingida a maioridade civil."

"Art. 1.565. Pelo casamento, homem e mulher assumem mutuamente a condição de consortes, companheiros e responsáveis pelos encargos da família."

É o que sustenta Marianna Chaves:

"ainda que se considerasse que a locução 'homem e mulher', constantes dos artigos. 1.514, 1.517 e 1.565 do CC, constituiriam "proibições implicitas", ao magistrado sempre cabe o controle difuso de constitucionalidade, podendo não aplicar ao caso concreto uma norma que considere inconstitucional. Todavia, já foi referido que não existem proibições implícitas no ordenamento brasileiro. Portanto, o casamento entre pessoas do mesmo sexo não é proibido. Assim, ainda que não consagrado explicitamente, é permitido desde já, não existindo nenhum obstáculo legal para que os homossexuais tenham acesso ao casamento, como atualmente regulamentado no ordenamento jurídico brasileiro. "(CHAVES,2011:293)

Ademais, considerando que são o afeto e o amor conjugal os elementos caracterizadores da família contemporânea, conforme 
demonstrado no primeiro capítulo do presente estudo, tem-se que é esse amor familiar o elemento valorativamente protegido pelo artigo 226 parágrafo $3^{\circ}$ da CF 88 c/c art. 1.723 e art. 1.514, ambos do CC. Com efeito, o referido artigo constitucional consagrou o princípio da pluralidade das entidades familiares em que a menção "homem e mulher" seria apenas exemplificativa, e não taxativa. É o que justifica Maria Berenice Dias:

"não há limites semânticos no texto do art. 226, parágrafo $3^{\circ}$, da CF88 ou nos arts. 1.514 e 1.723 do CC 2002, visto que dizer que é reconhecida a união estável 'entre homem e mulher' e que o casamento civil é o ato realizado quando o 'homem e a mulher' comparecem perante o juiz de paz significa meramente a regulamentação do fato heteroafetivo, sem proibição do fato homoafetivo para tais fins, visto que em direito de família somente os fatos citados pelos taxativos imepedimento matrimoniais podem ser tidos como 'proibidos'. Assim, não há afronta à interpretação literal. " (DIAS, 2011:155)

Para Daniel Sarmento:

"verifica-se que ele assegurou expressamente o reconhecimento da união estável entre homem e mulher, mas nada disse sobre a união civil dos homossexuais. Esta ausência de referência não significa, porém, silêncio eloqüente da Constituição. $O$ fato de que o texto omitiu qualquer alusão à união entre pessoas do mesmo sexo não implica, necessariamente, que a Constituição não assegure o seu reconhecimento.(...)Não bastasse, o elemento teleológico da interpretação constitucional também não é compatível com a leitura do art. 226, $\S 3^{\circ}$, da Constituição, segundo a qual do referido preceito decorreria, 'a contrario sensu', o banimento constitucional da união entre pessoas do mesmo sexo. Com efeito, o referido preceito foi inserido no texto constitucional no afã de proteger os companheiros das uniões não matrimonializadas, coroando um processo histórico que teve início na jurisprudência cível, e que se voltava à inclusão social e à superação do preconceito. Por isso, é um contra-senso interpretar este dispositivo constitucional, que se destina a 'inclusão', como uma cláusula de exclusão social, que tenha como efeito discriminar os homossexuais." (SARMENTO, 2008: 649-652)

$\mathrm{O}$ art. 226, em seu parágrafo $4^{\circ}$, por sua vez, nos confirma tal idéia: "Entende-se, também, como entidade familiar a comunidade formada por qualquer dos pais e seus descendentes". Assim, consta que se compreende também como entidade familiar a chamada família monoparental. A expressão "também" é uma conjunção aditiva a evidenciar que se trata de uma enumeração exemplificativa da entidade familiar e não taxativa. 
Por outro lado, há de se destacar que os impedimentos matrimoniais são as proibições expressamente elencadas pelo CC, no art. 1.521, ou em outros dispositivos difundidos que determinam a anulabilidade ou nulidade do casamento civil. Nestes artigos legais não se encontra qualquer proibição quanto à coincidência de sexos dos nubentes. Se fosse a intenção do legislador de vetar, teria feito expressamente com o novo Código Civil de 2002. No entanto, não o fez. E, conforme citação acima de Maria Berenice Dias, a interpretação que deve ser feita é que a referência à expressão "homem e mulher" é apenas uma regulamentação do fato heteroafetivo, sem que isso implique em uma proibição do fato homoafetivo.

Em outras palavras, a legislação se limitou a regular um fato deixando outro sem regulamentação mas que, ao mesmo tempo, não há qualquer vedação e sim uma lacuna, que deverá ser suprida pela interpretação extensiva ou analogia como previsto no art. $4^{\circ}$ da LICC: “Quando a lei for omissa, o juiz decidirá o caso de acordo com a analogia, os costumes e os princípios gerais de direito." E, também, no art. 126 do CPC: "O juiz não se exime de sentenciar ou despachar alegando lacuna ou obscuridade da lei. No julgamento da lide caber-lhe-á aplicar as normas legais; não as havendo, recorrerá à analogia, aos costumes e aos princípios gerais de direito":

É o que reconhece e propõe Maria Berenice Dias:

“(...) o silêncio constitucional e a omissão do CC não impedem que se extraiam efeitos jurídicos das uniões de pessoas do mesmo sexo. Apesar da ausência de regulamentação expressa à união e ao casamento homoafetivo, como não há qualquer proibição, o juiz tem o dever de julgar as lides que lhe são trazidas a julgamento. Precisa atender à determinação do art. $4^{\circ}$ da Lei de Introdução ao Código Civil e do art. 126 do CPC e fazer uso da analogia, dos costumes e dos principios gerais de direito". (DIAS, 2009:152-154) 
Neste ponto é de se considerar a máxima Kelseniana em que aquilo que não é expressamente proibido seria permitido, princípio que encontra proteção no art. $5^{\circ}$ inciso II da CF 88 , que prevê o princípio da legalidade segundo o qual ninguém será obrigado a deixar de fazer algo senão em virtude de lei. Nestas condições, não havendo lei expressa proibitiva, o que se tem é uma lacuna que deverá ser preenchida pela analogia ou por uma interpretação extensiva, em respeito à isonomia, mas isto quando o fato não citado pelo enunciado normativo possuir o mesmo valor protegido pelo fato citado pelo enunciado normativo. Do contrário, nos encontraríamos em um caos social.

O que se tem, então, é que toda união oriunda de um amor conjugal que vise uma comunhão plena de vida de forma pública, contínua e duradoura deve ser protegida pelos regimes do casamento civil e da união estável, a menos que um enunciado normativo expresso tido como constitucional proíba. Ressalte-se, ainda, que a decisão nesse sentido não implica usurpação da competência do Congresso Nacional e, consequentemente, afronta ao princípio da separação dos poderes decorrentes de "legislação positiva" do Poder Judiciário.

\section{Conforme ilustra com eloqüência Vecchiatti:}

"Reconhecer a possibilidade jurídica do casamento civil homoafetivo com base na interpretação extensiva ou na analogia (que não são formas de legislação positiva, mas de integração do ordenamento jurídico no caso concreto), implica apenas reconhecer o real objeto de proteção da lei do casamento civil, a saber o amor romântico que vise à comunhão plena de vida e interesses, de forma pública, contínua e duradoura, amor este que é o elemento formador da família contemporânea formada por casais. Isto porque, a partir do momento em que a lei expressa permite a utilização da interpretação extensiva e da analogia, significa que o ordenamento jurídico defere ao Judiciário o dever-poder de garantir à situação não-citada ou não-regulamentada pela norma o regime jurídico desta, como conseqüiência do princípio constitucional da igualdade. Nesse sentido, se o próprio Poder Legislativo permitiu ao Poder Judiciário integrar as lacunas normativas pela interpretação extensiva ou pela analogia (como formas de garantir isonomia), então não há que se falar em afronta ao princípio da separação dos poderes quando dita integração é efetivamente realizada. A lei já existe: a questão é que determinada situação (fato), que se encontra no objeto de 
proteção da norma (interpretação teleológica-valor) não foi por ela citada, razão pela qual deve ela ser protegida por ditas técnicas de integração do sistema jurídico e motivo este que demonstra inexistir "criação de lei" pelo Judiciário ao fazê-lo. Entendimento em contrário significa nada menos do que negar vigência aos dispositivos legais que consagram a interpretação extensiva e a analogia, $o$ que claramente não é o posicionamento correto. ”(VECCHIATTI, 2008:461)

Ademais, como não há lei que diga expressamente que os homoafetivos não podem constituir família juridicamente protegida, só podemos inferir que esses são, também, aptos a constituí-la. Compreender de maneira oposta seria ignorar os princípios da hermenêutica jurídica, além dos princípios da igualdade, dignidade da pessoa humana entre outros, como evidenciado em conexo capítulo desta obra e resumidos, ainda, nos $\operatorname{artigos} 3^{\circ}$ e $5^{\circ}$ da $\mathrm{CF}$ :

\footnotetext{
"Art. $3^{\circ}$ Constituem objetivos fundamentais da República Federativa do Brasil:

$I V$ - promover o bem de todos, sem preconceitos de origem, raça, sexo, cor, idade e quaisquer outras formas de discriminação."

"Art. 5': Todos são iguais perante a lei, sem distinção de qualquer natureza, garantindo-se aos brasileiros e aos estrangeiros residentes no País a inviolabilidade do direito à vida, à liberdade, à igualdade, à segurança e à propriedade"
}

É totalmente aplicável aqui, nesta oportunidade, o ensinamento de Konrad Hesse que dispõe que "a interpretação adequada é aquela que consegue concretizar, de forma excelente, o sentido da proposição normativa dentro das condições reais dominantes numa determinada situação razão pela qual uma mudança das relações fáticas pode-ou deve - provocar mudanças na interpretação da Constituição.” (HESSE, 1991:22-23). Deste modo, pela máxima efetividade das normas constitucionais, deve-se dar o sentido que proporcione maior eficácia às normas, especialmente no tocante aos direitos fundamentais, o que não acontece quando não são reconhecidos o casamento civil ou a união estável entre pessoas do mesmo sexo a par da mesma identidade de razão, qual seja, o amor familiar. 
Desta forma, dizer que é reconhecida a união estável entre homem e mulher é diferente de dizer que ela é reconhecida apenas entre o homem e a mulher. Não é possível reduzir formas de sentir, relacionamentos firmados e projetos de compartilhamento de vidas a um rol exaustivo ou a fórmulas preestabelecidas.

Conforme leciona Vecchiatti no livro coordenado pela Maria Berenice Dias:

"como o conceito de união estável e do casamento civil não está ligado indissociavelmente à diversidade de sexos pelo texto constitucional (o que ocorreria se estivesse escrito nos enunciados normativos que tais regimes jurídicos são reconhecidos 'apenas entre' o homem e a mulher), não há afronta ao conteúdo mínimo estrutural do texto jurídico da união estável e do casamento civil, donde não parece que haja algo que o texto diga que impossibilite o intérprete de adotar a tese aqui defendida (...) pois a união estável enquanto entidade familiar e o casamento enquanto entidade familiar, em seu sentido estrutural mínimo, é a união de fato pautada pelo amor conjugal que vise a uma comunhão plena de vida e de interesses, de forma pública, contínua e duradoura, pela qual os companheiros vivem como se casados fossem (...) (DIAS, 2011:158)

Em contrapartida, em razão dos princípios constitucionais estabelecidos na Carta Magna brasileira, não há necessidade de justificar o direito ao casamento entre pessoas do mesmo sexo. Pelo contrário, a negativa de acesso ao instituto jurídico do casamento às pessoas homossexuais é que deveria ser fundamentada.

Todavia, em função dos Cartórios de Registro Civil se recusarem a celebrá-lo, resta ao casal a possibilidade de intentar ação declaratória de possibilidade jurídica de tal união, com base na possibilidade jurídica do pedido por meio da interpretação extensiva ou analogia além da demonstração dos requisitos de validade do casamento. Acrescenta Vecchiatti: "Por outro lado, deve constar pedido alternativo de declaração de inconstitucionalidade do art 1.514 do Código Civil, caso o Judiciário entenda pela suposta 'proibição implícita' do casamento civil homoafetivo 
em atenção à redação do citado dispositivo legal." (VECCHIATTI, 2008:304-305)

\begin{abstract}
Destaca-se:
Tem-se por inconstitucional ${ }^{10}$ o art. 1.514 do Código Civil em virtude da suposta "proibição implícita" do direito ao casamento civil a homossexuais por ofensa direta ao princípio da isonomia. (...) Assim, se nem a doutrina nem a jurisprudência trazem uma correlação lógico-racional entre a discriminação jurídica que defendem e o critério de discriminação por elas erigido, então é flagrantemente inconstitucional a proibição do casamento civil homoafetivo por afrontar o preceito isonômico. (VECCHIATTI, 2008: 279 -81)
\end{abstract}

Diante todo o exposto, podemos afirmar ser o casamento civil homoafetivo um pedido juridicamente possível pela interpretação teleológica da lei do casamento civil, de acordo com as técnicas de integração do sistema jurídico. Tal afirmativa se fundamenta não apenas pela ausência de lei proibitiva expressa, mas também por uma interpretação sistemática do Direito. Isso porque a união amorosa formada por pessoas do mesmo sexo é idêntica ou, no mínimo, análoga à união heteroafetiva, o que demanda por um tratamento jurídico igualitário de acordo com os princípios da igualdade e da dignidade humana. A inexistência de menção legislativa expressa que a permita é irrelevante, em razão da interpretação extensiva e analogia, ambas previstas nos art. $4^{\circ}$ da LICC e 126 do CPC, respectivamente.

Assim, o entendimento é pela falta de necessidade de uma nova lei civil específica para regulamentar as uniões homoafetivas, posto que a lei civil já existe, que é a lei do casamento. É o que justifica Maria Berenice Dias:

\footnotetext{
10 “considerando que o sistema pátrio de controle de constitucionalidade possui tanto elementos de controle difuso como de controle concentrado, sendo assim perfeitamente possivel a declaração de inconstitucionalidade por qualquer juiz, e não apenas pelo Supremo Tribunal Federal, mesmo porque a eficácia da sentença que declarar a citada inconstitucionalidade terá apenas eficácia inter partes". (VECCHIATTI, 2008: 285)
} 
"A partir da nova definição de entidade familiar, trazida pela Lei Maria da Penha, não mais cabe questionar a natureza dos vínculos formados por pessoas do mesmo sexo. Ninguém pode continuar sustentando que, em face da omissão legislativa, não é possivel emprestar-lhe efeitos jurídicos(...) $O$ avanço é significativo, visto que coloca um ponto final à discussão que entretém a doutrina $e$ divide os tribunais. A eficácia da nova lei é imediata, passando as uniões homossexuais a merecer especial proteção do Estado (CF 226).” (DIAS, 2007:195)

No entanto, ainda que não proibida, a união homoafetiva ainda está no plano do não reconhecimento, pela ausência de inclusão legal expressa. Destarte, em nome da segurança jurídica que uma lei explícita oferece, assim como a tranquilidade de não ter que recorrer constantemente ao Poder Judiciário, é imperioso que sejam editadas as normas existentes, a fim de estabelecer expressamente a possibilidade de os homossexuais contraírem casamento. De fato as discussões acerca do tema da não discriminação por orientação sexual ganharam mais visibilidade apenas recentemente, nos anos 90, o que talvez justifique a sua ausência nas discussões do projeto do novo CC. No entanto, os operadores do direito devem procurar soluções enquanto se aguarda a aprovação legislativa, mas tal exclusão não pode continuar visto implicar em constantes injustiças.

Assim, caso prepondere o entendimento restritivo do casamento civil apenas a heterossexuais em razão da expressão "homem e mulher" constante nos dispositivos legais, há de se entender pela inconstitucionalidade do artigo 1.514 do CC, tendo em vista a ausência de motivação lógico-racional a justificar a necessidade da discriminação dos casais homoafetivos em relação aos heteroafetivos. Então, declarada a inconstitucionalidade, deverá ser o casamento civil reconhecido tanto a duas pessoas de sexos diversos quanto a duas pessoas do mesmo sexo, em interpretação conforme a Constituição.

Ademais, pelo fato dos Cartórios de Registro Civil se recusarem a celebrar o casamento, o entendimento é que o par interessado deve ingressar com uma ação declaratória de possibilidade jurídica de casamento 
civil homoafetivo, pelo rito ordinário, na qual demonstre os requisitos de validade do casamento, apresentando a fundamentação jurídica no sentido de sua possibilidade. Por outro lado, deve constar pedido alternativo de declaração de inconstitucionalidade do art. 1.514 do Código Civil, caso o Judiciário entenda pelo suposta "proibição implícita" do casamento civil homoafetivo em atenção à redação do citado dispositivo legal. 


\section{DIREITO COMPARADO: RECEPÇÃO DO TEMA NO SISTEMA JURÍDICO INTERNACIONAL}

“Seja a mudança que você deseja ver no mundo"-Mahatma Gandhi

A polêmica acerca da aceitação da homossexualidade está presente em praticamente todo o mundo. Diversos países vêm inserindo em suas legislações as uniões homoafetivas, seja reconhecendo-as através da união civil, do próprio casamento ou outra denominação. Maria Berenice Dias aponta para a existência de estudos que evidenciam que os Estados que atingiram o mais elevado nível sócio econômico cultural são aqueles em que existe a promoção para integração das minorias, além de favorecimento para o desenvolvimento da identidade de tais grupos.

De fato, a importância do direito comparado implica em um melhor conhecimento e compreensão do seu próprio direito evidenciando suas peculiaridades e possibilitando, também, um estudo mais aprofundado daquilo que a legislação nacional não concede. Isso porque a utilidade do direito comparado se fundamenta em informar, de modo rigoroso, sobre as instituições estrangeiras, procurando em suas experiências os meios técnicos de suprir lacunas do direito nacional.

No Brasil a questão permanece em discussão no Poder Legislativo, para que sejam elaboradas regras específicas, com o objetivo de disciplinar e conferir efeitos jurídicos a essas uniões. Em realidade, os casais homossexuais se encontram em situação de desamparo legal e é o Poder Judiciário que vem solucionando a questão por meio de regras de hermenêutica, como a interpretação extensiva, analogia e os princípios gerais do Direito. 
Este capítulo propõe uma análise geral de alguns países que possuam norma de relevo referente às pessoas do mesmo sexo. Cumpre destacar, ainda, que se trata de um panorama superficial, com o objetivo de apresentar o atual cenário jurídico internacional das relações homoafetivas.

\section{- Dinamarca}

A Dinamarca em junho de 1989 , foi a pioneira em reconhecer a homoafetividade, permitindo o registro da união civil e estendendo aos casais homoafetivos os mesmos benefícios sociais dos heteroafetivos, contudo não aceitava ainda a adoção, o que veio a reconhecer, sendo mais uma vez a pioneira, em 1999.

Marianna Chaves complementa:

"Atualmente, não existe mais o requisito da nacionalidade dinamarquesa para que os conviventes possam levar a cabo a sua parceria registrada. $O$ requisito agora se limita a que, pelo menos um deles, seja residente no país há dois anos. Ademais, noruegueses, suecos e islandeses serão tratados como se dinamarqueses fossem, pois suas leis de parceria registrada são similares à dinamarquesa. Para outros países, com leis de parceria registrada correspondentes à dinamarquesa, o Ministro da Justiça determinou que aquela nacionalidade será tratada igualitariamente à nacionalidade da Dinamarca" (CHAVES, 2011:115)

\section{-Noruega:}

Em 1993, a Noruega permitiu o registro civil das uniões homoafetivas. Para proceder a tal registro, pelo menos um membro do par deveria ser norueguês e domiciliado no país. Em sentido amplo, as conseqüências legais eram as mesmas do casamento.

No entanto, a situação mudou em 11 de junho de 2008, quando uma proposta de Lei de Abertura de Casamento foi aprovada pelo parlamento norueguês. A referida norma entrou em vigor em $1^{\circ}$ de janeiro de 2009, equiparando os casais homossexuais aos heterossexuais para todos os 
efeitos do matrimônio, incluindo-se a possibilidade de se casar na Igreja. Este é o sexto país do mundo que reconhece o direito ao casamento.

\section{-Suécia:}

Na Suécia, através da Lei da Parceria Registrada, aprovada em 1994, foram garantidos às relações homoafetivas os mesmos direitos das heteroafetivas. O objetivo foi conceder aos pares do mesmo sexo a mesma estrutura jurídica encontrada no matrimônio. Vale destacar que tal registro não é aberto aos casais heterossexuais que não desejam casar.

A lei prevê que os dispositivos legais relativos ao casamento também sem apliquem à parceria registrada. Assim, os parceiros possuem a obrigação de ajuda mútua, podem adotar o sobrenome do outro e são herdeiros legais um do outro.

Ademais, em $1^{\text {o }}$ de abril de 2009, o Parlamento sueco aprovou as propostas legislativas que trouxeram a permissão para que aos homossexuais seja permitido o casamento civil. A lei entrou em vigor a partir de $1^{\circ}$ de maio do mesmo ano. No entanto, com a coexistência de leis, há de se destacar que a Lei de Parceria Registrada continua em vigor, constituindo uma opção de organização de vida dos casais homossexuais. Isso porque aqueles que almejem converter a parceria em casamento, o podem fazer, sem problemas, por um formulário escrito ou através de cerimônia formal.

\section{-Suíca:}

Em 2007, foi publicada lei federal, que protegia as uniões homoafetivas, contudo, mesmo antes disso, Genebra, Zurique e Neuchâtel já tinham leis estaduais que as protegiam. 


\section{-Israel:}

No ordenamento jurídico israelense os problemas enfrentados pelos casais de mesmo sexo possuem um grau de dificuldade maior, em comparação com outros Estados. Isso porque o direito de família é governado por normas religiosas ortodoxas. Casais do mesmo sexo não podem se casar e nem registrar parceria em Israel.

No entanto, as normas aplicáveis aos casais heterossexuais passaram a ser estendidas aos parceiros homossexuais nos últimos anos. Todavia, ainda que tal extensão ainda seja objeto de controvérsia nos Tribunais de Família israelenses, já se compreende que tais relações são tão comuns que seria injusto conceder tratamento distinto em relação às pessoas unidas pelo casamento.

É o que afirma Marianna Chaves:

"Relativamente ao patrimônio dos unidos factualmente, existe uma presunção de comunhão de bens entre os partícipes da união de fato. Mesmo que o bem esteja registrado em nome de apenas um dos indivíduos, tal fator não afasta, de imediato, a presunção. (...) É mister ressaltar que tais pares são legalmente qualificados para receber as mesmas pensões e benefícios de seguridade que os pares casados. Em relação ao direito sucessório, tais pares possuem os mesmos direitos que os cônjuges, a não ser que o falecido tenha atestado de forma diversa". (CHAVES, 2011:138)

Vale destacar que Israel se diferencia por ser atualmente o único país que reconhece casamentos homoafetivos feitos fora do país, embora não os realize, simplesmente porque não existe casamento civil em Israel mas apenas o religioso com efeitos civis. Assim, as pessoas somente podem se casar dentro das comunidades religiosas reconhecidas pelo Estado já que relativamente à jurisdição, as decisões de questões de casamento e divórcio são de competência dos tribunais religiosos. Tal fato obriga casais (homossexuais ou heterossexuais) não-religiosos ou de religiões diferentes a se casarem no exterior para terem depois o casamento reconhecido pelo Estado. 


\section{-Holanda:}

A Holanda reconhecia a união civil desde 1998, conferindo direito à saúde, à educação e aos benefícios trabalhistas, sendo que em 2001, regulamentou também o casamento homoafetivo com idênticas consequências ao heteroafetivo, sendo assegurada também a possibilidade de adoção.

\section{-Finlândia:}

Em 2001, a Finlândia legalizou as relações entre maiores de 18 anos, permitindo-lhes seu registro em cerimônia comparáveis ao casamento civil. Desta forma, há a possibilidade de serem oficialmente registradas as parcerias civis homossexuais.

\section{-Inglaterra:}

A Inglaterra criou em 2004 o Registro de Parceria de casais homoafetivos com o advento da Civil Partnership Act. No entanto, tal registro concedia muitos efeitos similares ao casamento, sem equiparar os institutos, no entanto.

De fato, com o surgimento da lei, os casais do mesmo sexo passaram a ter acesso a uma gama de direitos, tais como: de propriedade, isenção do imposto sobre herança, pensões e reconhecimento para seguros de vida.

\section{-Alemanha:}

Em janeiro de 2000, o Ministro da Justiça alemão publicou a primeira versão de uma Proposta de Lei sobre a "parceria de vida", que previa que a seria registrada parceria nos mesmos moldes do casamento heterossexual. No final do mesmo ano, a versão final da referida Lei foi dividida em duas. 
Sendo aprovada a primeira proposta, em 10 de novembro de 2000, foi permitido o registro das uniões com nome de "parceria de vida", concedendo alguns benefícios sociais e reconhecendo o parceiro do mesmo sexo como parente mais próximo. De acordo com a normativa, os parceiros podem adotar o sobrenome um do outro, escolher o regime de bens aplicável à relação.

A segunda PL que incluía mais direitos correlatos ao matrimônio foi vetada em $1^{\circ}$ de dezembro de 2001. Esta concedia diversos benefícios de ordem econômica aos casais homossexuasis, como os relativos à tributação, ao imposto de renda em comum, ao direito à herança e à igualdade de vantagens para servidores públicos.

Vale destacar que a lei aprovada enfrentou oposição de estados conservadores que apresentaram recurso à Suprema Corte Alemã, pleiteando pela inconstitucionalidade da norma, sob fundamento de que essa normativa representava uma violação à proteção constitucional do matrimônio. No entanto, em 18 de julho de 2001, os juízes confirmaram sua constitucionalidade.

\section{-Bélgica:}

A Bélgica foi o segundo país no mundo, posteriormente a Holanda, a permitir o casamento entre pessoas do mesmo através da Loi Ouvrant Le Mariage à des Personnes de Même Sexe Et Modifiant Certaines Dispositions Du Code Civil, de 13 de fevereiro de 2003. O direito à adoção existe, ainda, desde 01.12.2005.

A referida Lei de abertura do matrimônio concedeu nova redação a diversos dispositivos do Código Civil. Desta forma, os requisitos para o casamento são iguais, tanto para os casais homossexuais, como para os 
heterossexuais. Faz-se necessário que ao menos um dos nubentes seja natural da Bélgica, ou residente do país.

\section{-EUA:}

Nos Estados Unidos da América, a legislação pertinente é estadual. Dos seus cinquenta Estados, dez conferem direitos a união homoafetiva. Sobre este país merece destaque a afirmativa de Marianna Chaves:

"Determinados países acharam maneiras outras de conceder direitos legais aos pares não unidos pelo matrimônio, envolvendo tais questões.Note-se que sob esse ponto de vista, há quem sustente que o problema nos EUA não se centra na negação do acesso ao casamento a gays e lésbicas, mas na questão que o Estado norte-americano supervaloriza os pares casados, sendo a eles restrito o acesso às leis de que todas as famílias necessitam. Os que se filiam a essa corrente asseveram que o que se busca é a paridade de direitos. Assim, havendo uma figura que concedesse os mesmos direitos que o casamento, a busca incessante pelo acesso ao instituto perderia a sua razão de ser. Em sentido contrário, há quem afirme que o acesso ao casamento deve constituir mais que uma isonomia semântica, uma igualdade de direitos e deveres. Nessa corrente, entende-se que existe a necessidade de se abrir o instituto do casamento aos homossexuais." (CHAVES, 2011:119)

Massachusetts, em 2004, foi o primeiro estado norte-americano a reconhecer o casamento homoafetivo, sendo que em 2003 já havia reconhecido a inconstitucionalidade de uma lei que impedia o mesmo.

Em 2007, Connecticut também admitiu o casamento. A união civil foi reconhecida em Nova Jersey no ano de 2007 e em New Hampshire em 2008. O Havai, em 1997, instituiu a figura do "beneficiário recíproco", na Califórnia, em 1999, as parcerias domésticas, assim como em Maine, em 2004, Columbia, em 2006, Washington, em 2007 e Oregon, em 2008, concedendo direitos aos parceiros.

Em maio de 2008, a Califórnia declarou inconstitucional lei que não admitia o casamento homoafetivo, contudo, houve em novembro um retrocesso, por meio de plebiscito, aprovando-se uma emenda para impedilo. 


\section{-África Do Sul:}

O progresso mais recente se deu com a aprovação do Civil Union Act, que entrou em vigor em 30 de novembro de 2006, passando a permitir que os casais homossexuais se casem.

Os objetivos da referida Lei são a regulação da celebração e registro das uniões civis, tanto sob a forma de patrimônio como parceria civil, e a fixação das consequiências legais de tais uniões. Há de se destacar que a normativa abrange uniões hetero e homoafetivas.

\section{-Espanha:}

Espanha também aprovou casamento e adoção homoafetiva, através de alteração do seu Código Civil com o advento da Lei 13/2005. A reforma acrescenta um parágrafo que dispõe que o matrimônio terá os mesmos requisitos e efeito quando ambos os contraentes sejam do mesmo sexo ou sexo distinto.

Destaca-se que, mesmo com a quebra do paradigma da heterossexualidade como requisito para o casamento, o regime jurídico deste se manteve inalterado no seu conteúdo. Assim, a modificação é puramente terminológica: foi substituída a expressão "marido e mulher" pelo termo genérico "cônjuges" ou "consortes".

\section{-Canadá:}

Acolheu o matrimônio concedendo os mesmos direitos aos homoafetivos com a aprovação pelo Parlamento do Civil Marriage Act em 28 de junho de 2005 e seguida ratificação do Senado em 19 de julho, entrando em vigor no dia seguinte. A constitucionalidade de tal Lei do Casamento Civil foi questionada perante o Supremo Tribunal Canadense, que se manifestou pela validade da mesma. 


\section{-República Tcheca:}

Na República Tcheca, a Lei de Parceria Registrada foi aprovada em março de 2006, entrando em vigor em $1^{\circ}$ de julho do mesmo ano. Através da normativa, foram estendidos aos homoafetivos benefício de planos de saúde, direito à pensão em caso de morte, direito alimentos, visitação em hospital e decisão sobre funeral do companheiro.

\section{-México:}

Em 2006, a Cidade do México aprovou as uniões civis homoafetivas pela Lei de Sociedade de Convivência, concedendo direito de propriedade, pensão, herança e direitos familiares, entretanto não admite adoção.

Posteriormente, em 21 de dezembro de 2009, a Cidade do México se tornou a primeira jurisdição latino-americana a aprovar o casamento civil homoafetivo. A Lei entrou em vigor no dia 4 de março de 2010 e teve a sua constitucionalidade questionada. Em 5 de agosto, por 8 votos a 2, o Supremo Tribunal do México se manifestou pela constitucionalidade da normativa.

\section{-Argentina:}

Em 2002, Buenos Aires e Rio Negro foram as primeiras cidades da América Latina a conceder direitos, como plano de saúde e pensão em caso de morte de um dos companheiros, independente do sexo e da orientação sexual, por outro lado não autorizou o casamento e adoção homoafetivos.

Em julho de 2010 foi promulgada a Lei 26.618 que modificou diversos dispositivos do Código Civil argentino de forma a permitir o casamento entre pessoas do mesmo sexo. A mudança no artigo específico disciplina que o matrimônio terá os mesmos requisitos e efeitos, independentemente da diferença ou igualdade de sexo dos contraentes. A 
Argentina torna-se, portanto, o primeiro país da América Latina a autorizar o casamento homoafetivo.

\section{-Portugal:}

O Código Civil português era bem explícito ao afirmar no seu artigo 1.577 que "o casamento era o contrato celebrado entre duas pessoas de sexo diferente que pretendem constituir família mediante uma plena comunhão de vida". Em outro dispositivo, em seu artigo 1628, assegurava que o casamento contraído por duas pessoas do mesmo sexo seria juridicamente inexistente.

Porém, em 17 de novembro de 2009 o Governo de Portugal aprovou uma Proposta de Lei que permitiria o casamento civil homossexual. Esta passou a entrar em vigor em maio de 2010.

A respeito dos outros países, vale destacar que em 1996, a Islândia, Hungria e Groelândia aprovaram leis que atribuem as uniões homoafetivas os mesmos direitos do casamento. Em 2004, Luxemburgo, Itália e Austrália, Andorra e Eslovênia concederam direitos aos parceiros homoafetivos. O mesmo ocorreu na Nova Zelândia, em 2005.

Em suma, admitem em sua legislação o casamento homoafetivo: África do Sul, Argentina, Bélgica, Canadá, Espanha, Holanda, Islândia, Noruega, Portugal e Suécia.

No entanto, apesar da evolução do cenário internacional quanto a homoafetividade em mais de setenta países do mundo, essa orientação sexual ainda é considerada crime. Principalmente nos países islâmicos e muçulmanos mais radicais, como o Afeganistão, a Arábia Saudita, os Emirados Árabes e o Sudão, em que até hoje, a repressão à manifestação da homoafetividade, tanto masculina como a feminina, culmina na pena de 
morte. Isso porque a interpretação que normalmente os líderes religiosos dão a seus livros sagrados é a que Deus seria contrário à união amorosa entre pessoas do mesmo sexo.

É o que frisa Marianna Chaves:

"Países como Afeganistão, Arábia Saudita, Sudão e Emirados Árabes Unidos, onde a homossexualidade ainda pode custar a vida. No Irã, os homossexuais podem, além de sofrer a ameaça de perder a vida, ter os pés ou mãos amputados. No Paquistão a lei é silente em relação às mulheres, mas os homossexuais masculinos podem ser condenados à prisão perpétua. Na Romênia, BieloRússia e Bósnia Herzegovina, os atos homossexuais permanecem proibidos, com a pena de prisão para quem praticá-los." (CHAVES, 2011:104)

Inclusive, tais países são os principais responsáveis, em função dessa política, pela elaboração dos Princípios de Yogykarta $^{11}$. Tais princípios tratam de um amplo espectro de normas de direitos humanos e de sua aplicação visando combater a discriminação por orientação sexual $e$ identidade de gênero, no sentido de que os países deixem de perpetrar tais discriminações mediante a garantia de direitos ali especificados, que nada mais são do que aplicações dos direitos humanos fundamentais. (VECCHIATTI, 2008:568). Assim, esses princípios afirmam normas jurídicas internacionais vinculantes, a serem cumpridas por todos os Estados. São feitas, pois, recomendações adicionais às Nações Unidas, instituições nacionais de direitos humanos e organizações não governamentais.

\footnotetext{
${ }^{11}$ Em novembro de 2006, em Yogyakarta, Indonésia, foi realizada conferência coordenada pela Comissão Internacional de Juristas e o Serviço Internacional de Direitos Humanos a fim de desenvolver um conjunto de princípios internacionais sobre o assunto.
} 


\section{EXPERIÊNCIA BRASILEIRA: DECISÕES, LEGISLAÇÃO E JURISPRUDÊNCIA}

"Na aritmética do amor um mais um é igual a um"- Jean Paul Sartre

\section{Decisões e Jurisprudência}

Como se apenas houvesse caráter comercial e fins meramente lucrativos, as controvérsias entre companheiros eram julgadas pelas Varas Cíveis. Os bens amealhados durante o período de convívio eram divididos, operando-se verdadeira divisão de lucros, tendo tais relações apenas efeitos patrimoniais, como se sociedade de fato fossem. No entanto, começa a surgir uma nova orientação jurisprudencial através de esparsas decisões em todo o país sobre a natureza familiar das uniões homoafetivas.

A primeira decisão do Poder Judiciário que reconheceu como entidade familiar a união homoafetiva foi um Tribunal gaúcho em $1999{ }^{12}$. Tal julgado deslocou no Rio Grande do Sul a competência da Vara Cível para a de Família, sede competente para dirimir situações que envolvem relações de afeto, o que significa a remessa de todas as demandas que já tramitavam nas varas cíveis para a jurisdição de família. Trata-se de um grande avanço na medida em que seriam concedidos efeitos jurídicos a essas uniões e reconhecendo, então, direitos até então tidos como inexistentes quando, por exemplo, do desfazimento dos vínculos, pela $\begin{array}{lllll}\text { separação } & \text { ou } & \text { em } & \text { virtude } & \text { da }\end{array}$

\footnotetext{
${ }^{12}$ TJRS, AI599075496, 8 a Câmara Cível, rel. Des. Breno Moreira Mussi, j.17.06.1999.
} 
No ano de 2001, o mesmo Tribunal aplicou a analogia e os princípios da igualdade e dignidade da pessoa humana para assegurar o direito de herança a parceiro homossexual ${ }^{13}$ e reconhecendo, também, a união homossexual como entidade familiar. Tal julgamento retirou o vínculo afetivo homossexual do direito das obrigações, em que era visto como simples negócio. Deste modo, outros Tribunais tais como Bahia, Rio de Janeiro, Paraná, Minas Gerais e São Paulo, passaram a reconhecer a competência das Varas de Família para o julgamento de demandas concernentes a uniões homossexuais.

As manifestações dos tribunais superiores, por sua vez, balizam as decisões das demais instâncias. O TSE ${ }^{14}$, em 2004, reconheceu a inelegibilidade da companheira da prefeita de uma cidade do Pára, por não ter se licenciado seis meses antes do pleito, com fulcro na $\mathrm{CF}$, que proíbe que cônjuges de Prefeitos concorram a qualquer cargo eletivo. Sobre a inelegibilidade da companheira, Maria Berenice Dias:

\footnotetext{
"O Tribunal Superior Eleitoral, ao proclamar a inegibilidade $\left(C F 14 \$ 7 .^{\circ}\right)$ nas uniões homossexuais, reconheceu que a união entre duas pessoas do mesmo sexo é uma entidade familiar, tanto que a sujeita à vedação que só existe mo âmbito das relações familiares. Ora, se estão sendo impostos ônus aos vínculos homoafetivos, mister é que sejam assegurados também todos os direitos $e$ garantias a essas uniões no âmbito do direito das famílias $e$ do direito sucessório."(DIAS, 2007:194)
}

Nestas condições, a Corte Máxima Eleitoral reconheceu a união homoafetiva como entidade familiar, tendo em vista que a vedação da inelegibilidade ocorre no âmbito das relações familiares. Assim, com o objetivo de evitar a perpetuação do poder dentro de um mesmo núcleo

\footnotetext{
${ }^{13}$ TJRS, AC 70001388982, 7 Câmara Cível, rel. Des. José Carlos Teixeira Giorgis, j. 14.03.2001. Em brilhante decisão, o relator chamou a atenção para a própria postura do Poder Judiciário: "Não se permite mais o farisaísmo de desconhecer a existência de uniões entre pessoas do mesmo sexo e a produção de efeitos jurídicos derivados dessas relações homoafetivas. Embora permeadas de preconceitos, são realidades que o judiciário não pode ignorar."

${ }^{14}$ TSE, REsp Eleitoral n. 24564, relator: Min. Gilmar Mendes, julgamento: 01/10/2004.
} 
familiar, a aplicação do artigo 14 parágrafo $7^{\circ}$ da $\mathrm{CF}$ foi estendida não somente ao casamento, união estável ou concubinato, mas também à união homoafetiva, em razão de ser considerado igualmente forte o vínculo afetivo já que na seara eleitoral, não se pode vislumbrar a presunção de interesses políticos comuns.

Segue abaixo a ementa da decisão em análise:

"REGISTRO DE CANDIDATO. CANDIDATA AO CARGO DE PREFEITO. RELAÇÃO ESTÁVEL HOMOSSEXUAL COM A PREFEITA REELEITA DO MUNICÍPIO. INELEGIBILIDADE. ART. $14, \S 7^{\circ}, \quad D A$ CONSTITUIÇÃO FEDERAL.

Os sujeitos de uma relação estável homossexual, à semelhança do que ocorre com os de relação estável, de concubinato e de casamento, submetem-se à regra de inelegibilidade prevista no art. $14, \S 7^{\circ}$, da Constituição Federal.

Recurso a que se dá provimento."

Em $2003^{15}$, o Ministro Marco Aurélio, enquanto presidente do STF, negou recurso do INSS, ao pagamento de pensão ao companheiro de um homoafetivo por reconhecer a união homoafetiva como entidade familiar Em $2006^{16}$, o Ministro Celso Mello, extinguiu a ADI 300 por impugnar uma norma legal já revogada (o art. $1^{\circ}$ da Lei 9.278/96, que regulamentava o art 226 parágrafo $3^{\circ}$, foi derrogado pelo art. 1.723 do CC) mas demonstrou, mesmo não conhecendo da referida ação, que a união homoafetiva deve ser reconhecida como entidade familiar. De fato, o óbice para a análise do mérito foi justamente que era requerida na ADI 3300 a inconstitucionalidade da Lei revogada (9.278 de 1996). O Ministro sugeriu, então, a saída correta para o caso, que era a ADPF. Segue ementa:

"EMENTA: UNIÃO CIVIL ENTRE PESSOAS DO MESMO SEXO. ALTA RELEVÂNCIA SOCIAL E JURÍDICO-CONSTITUCIONAL DA QUESTÃO PERTINENTE ÀS UNIÕES HOMOAFETIVAS. PRETENDIDA QUALIFICAÇÃO DE TAIS UNIÕES COMO ENTIDADES-FAMILIARES. DOUTRINA. Alegada inconstitucionalidade do art 1 da Lei 9.278/1996. Norma legal derrogada pela

\footnotetext{
${ }^{15}$ STF, Pet. n. 1984/RS, relator: Min. Marco Aurélio, julgamento: 10/02/2003.

${ }^{16}$ STF, Informativo 414 (ADI n. 3300), relator: Min. Celso de Mello, julgamento: 03/02/2006.
} 
superveniência do art. 1.723 do CC/2002, que não foi objeto de impugnação nesta sede de controle abstrato. Inviabilidade, por tal razão, da ação direta. Impossibilidade jurídica, de outro lado, de se proceder à fiscalização normativa abstrata de normas constitucionais originárias (CF, art. 226, p. 3, no caso). Necessidade, contudo, de se discutir o tema das uniões estáveis homoafetivas, inclusive para efeito de sua subsunção ao conceito de entidade familiar: matéria a ser veiculada em sede de ADPF?"

E, assim, a ADPF foi ajuizada pelo governador do Estado do Rio de Janeiro, Sérgio Cabral, em 27.02.2008, e recebeu o número 132. Tal ação teve como objetivo que fosse aplicado o regime jurídico das uniões estáveis, previsto no art. 1723 do $\mathrm{CC}$, às uniões homoafetivas de funcionários públicos do Estado e contou, inclusive, com parecer favorável da AGU, proferido em 10.06.2008 pelo advogado-geral da União, José Antonio Dias Toffoli, para quem as uniões homoafetivas devem ser tratadas, juridicamente, como entidades familiares

A referida ADPF foi julgada procedente pelo STF em maio de 2011, juntamente com a ADI 4277, concernente esta ao reconhecimento da união entre pessoas do mesmo sexo como entidade familiar. Tal procedência configura um marco histórico visto que os onze ministros do STF se posicionaram, de forma unânime, pela constitucionalidade da união homossexual no Brasil. No entanto, isso não significa que a questão fique resolvida. Por mais importante que seja tal vitória, apenas com uma mudança autorizadora expressa na lei para que homossexuais sejam realmente tratados como iguais e que efetivamente tenham o direito ao casamento e à adoção conjunta de crianças.

O STJ ${ }^{17}$, por sua vez, no final de 2005 , um acórdão da sua $6^{\text {a }}$ Turma fez menção, pela primeira vez, ao neologismo homoafetivo e assegurou o direito do companheiro homossexual à pensão por morte. Eis a ementa do procedente:

\footnotetext{
${ }^{17}$ STJ, REsp 395.904/RS, 6 T, j. 13.12.2005, rel. Min. Hélio Quaglia Barbosa.
} 
“RECURSO ESPECIAL. DIREITO PREVIDENCIÁRIO. PENSÃO POR MORTE. RELACIONAMENTO HOMOAFETIVO. POSSIBILIDADE DE CONCESSÃO DO BENEFÍCIO. MINISTÉRIO PÚBLICO. PARTE LEGÍTIMA. (...) Diante do p. 3 do art. 16 da lei 8.213/1991, verifica-se que o que o legislador pretendeu foi, em verdade, ali gizar o conceito de entidade familiar, a partir do modelo da união estável, com vista ao direito previdenciário, sem exclusão, porém da relação homoafetiva.

6. Por ser a pensão por morte um benefício previdenciário, que visa suprir as necessidades básicas dos dependentes do segurado, no sentido de lhes assegurar subsistência, há que interpretar os respectivos preceitos partindo da própria Carta Política de 1988 que, assim estabeleceu, em comando específico: 'Art 201. Os planos de previdência social, mediante contribuição, atenderão, nos termos da lei, a: (...) V-pensão por morte de segurado, homem ou mulher, ao cônjuge ou companheiro e dependentes, obedecido o disposto no p. 2.'

7.Não houve, pois, de parte do constituinte exclusão dos relacionamentos homoafetivos, com vista à produção de efeitos no campo do direito previdenciário, configurando-se mera lacuna, que deverá ser preenchida a partir de outras fontes do direito.

8.Outrossim, o próprio INSS, tratando da matéria, regulou, através da IN 25 de 07.06.200, os procedimentos com vista à concessão de benefício ao companheiro ou companheira homossexual, para atender a determinação judicial expedida pela juíza Simone Barbasin Fortes, da Terceira Vara Previdenciária de Porto Alegre, ao definir medida liminar na ACP 200.71.00.009347-0, com eficácia erga omnes. Mais do que razoável, pois, estender-se tal orientação, para alcançar situações idênticas, merecedoras do mesmo tratamento.

9.Recurso Especial não provido"

Em outra oportunidade, em decisão histórica no ano de $2008^{18}$, o STJ começou a modificar sua jurisprudência sobre as uniões homoafetivas, até então consideradas por este Tribunal como sociedades de fato e passou a fixar, implicitamente, a competência das Varas de Família. Tal decisão não analisa o mérito, contudo permite o julgamento pelas varas de famílias estaduais das ações envolvendo questões decorrentes da união homoafetiva. Foi reconhecida, pois, a possibilidade jurídica da ação declaratória de união homoafetiva, sob o fundamento de que não existe vedação legal para o prosseguimento do feito.

Neste caso específico, dois companheiros, um brasileiro e outro canadense, ajuizaram ação declaratória da união homoafetiva mantida desde o ano de 1988. Casados no Canadá, país cuja legislação prevê o casamento homoafetivo, buscaram regularizar no Brasil a união estável, em razão da

\footnotetext{
${ }^{18}$ Superior Tribunal de Justiça. REsp no 820.475 - RJ (2006/0034525-4). Relator Min. Antônio de Pádua Ribeiro. Acórdão de 02 de set. de 2008)
} 
necessidade do companheiro estrangeiro obter visto de permanência. No entanto, o Poder Judiciário do Estado do Rio de Janeiro extinguiu o feito sem resolução do mérito por impossibilidade jurídica do pedido. O STJ, a teor do art $4^{\circ}$ da LICC, decidiu que, sendo omissa a lei, o juiz deve aplicar a analogia, reconhecendo a união homoafetiva, tendo em vista ser análoga ao instituto da união estável. Segue a ementa:

\begin{abstract}
PROCESSO CIVIL. AÇÃO DECLARATÓRIA DE UNIÃO HOMOAFETIVA. PRINCÍPIO DA IDENTIDADE FÍSICA DO JUIZ. OFENSA NÃO CARACTERIZADA AO ARTIGO 132, DO CPC. POSSIBILIDADE JURÍDICA DO PEDIDO. ARTIGOS $1^{\circ}$ DA LEI 9.278/96 E 1.723 E 1.724 DO CÓDIGO CIVIL. ALEGAÇÃO DE LACUNA LEGISLATIVA. POSSIBILIDADE DE EMPREGO DA ANALOGIA COMO MÉTODO INTEGRATIVO.
\end{abstract}

1. Não há ofensa ao princípio da identidade física do juiz, se a magistrada que presidiu a colheita antecipada das provas estava em gozo de férias, quando da prolação da sentença, máxime porque diferentes os pedidos contidos nas ações principal e cautelar.

2. O entendimento assente nesta Corte, quanto a possibilidade jurídica do pedido, corresponde a inexistência de vedação explícita no ordenamento jurídico para o ajuizamento da demanda proposta.

3. A despeito da controvérsia em relação à matéria de fundo, o fato é que, para a hipótese em apreço, onde se pretende a declaração de união homoafetiva, não existe vedação legal para o prosseguimento do feito.

4. Os dispositivos legais limitam-se a estabelecer a possibilidade de união estável entre homem e mulher, dês que preencham as condições impostas pela lei, quais sejam, convivência pública, duradoura e contínua, sem, contudo, proibir a união entre dois homens ou duas mulheres. Poderia o legislador, caso desejasse, utilizar expressão restritiva, de modo a impedir que a união entre pessoas de idêntico sexo ficasse definitivamente excluída da abrangência legal. Contudo, assim não procedeu.

5. É possível, portanto, que o magistrado de primeiro grau entenda existir lacuna legislativa, uma vez que a matéria, conquanto derive de situação fática conhecida de todos, ainda não foi expressamente regulada.

6. Ao julgador é vedado eximir-se de prestar jurisdição sob o argumento de ausência de previsão legal. Admite-se, se for o caso, a integração mediante o uso da analogia, a fim de alcançar casos não expressamente contemplados, mas cuja essência coincida com outros tratados pelo legislador.

Recurso especial conhecido e provido.

Assim, tal decisão se destacou não apenas por ter representado uma grande mudança no posicionamento do STJ, mas também por ter criticado os obstáculos ao reconhecimento dos direitos dos homossexuais. Cada vez 
mais, julgadores de todo o país vêm reafirmando, em adequados argumentos, que tais uniões formam entidades familiares e que um tratamento especializado deve ser garantido, ficando a cargo, pois, de julgadores mais familiarizados com a matéria. Trata-se de questão primordial para que se assegure a justiça.

É o que frisa Maria Berenice Dias a respeito de tal decisão em seu artigo "O começo do fim da invisibilidade":

"A decisão não significa que o STJ reconhece a existência do vínculo entre ambos e nem declara que se trata de uma união estável. Mas toma uma posição sobre tema envolto em preconceito e alvo de tanta discriminação que leva o legislador a omitir-se. Daí o significado do julgamento, pois impõe a inclusão das uniões homoafetivas no âmbito de proteção do sistema jurídico como uma realidade merecedora de tutela. Pela primeira vez é admitido, por um Tribunal Superior que as pretensões envolvendo pares homossexuais merecem ser apreciadas pela justiça. Aliás, neste sentido já vem se manifestando, de forma cada vez mais freqüente, tanto justiça comum como as justiças especializadas de vários Estados. “

No entanto, inobstante o STJ já ter decido que as questões que se referem às uniões homoafetivas devem ser tratadas em Varas de Família, muitos julgadores insistem em não fazê-lo, sob o argumento de que entre pessoas do mesmo sexo não seria possível a união estável. Afirmam que não existe lacuna na lei, alegam que tanto a $\mathrm{CF}$, quanto o $\mathrm{CC}$ são claros ao estabelecer que a união estável exige a dualidade de sexos, acabando, pois, em extinguir processos por impossibilidade jurídica do pedido, sendo esta a forma mais cruel e simplista de aniquilar direitos. Trata-se de uma posição preconceituosa e discriminatória que provoca uma privação de direitos e ainda afronta a Constituição ao proibir aos homoafetivos o direito à família e ao não garantir a crianças e adolescentes o direito à convivência familiar.

Em outro julgamento mais recente, em 2010, o STJ $^{19}$ reafirma tal direito de quem vive em uniões de afeto de ser reconhecido como

\footnotetext{
${ }^{19}$ STJ, REsp 1.026.981/RJ, 4 T., rel. Min. Nancy Andrigny, j. 04.02.2010.
} 
dependente do segurado fazendo jus à pensão por morte. Essa decisão ratificou a orientação já uniforme nos tribunais federais e de um enorme número de decisões nos tribunais estaduais. A Relatora, Min. Fátima Nancy Andrigny, ao admitir os parceiros do mesmo sexo como dependentes preferenciais dos segurados, é categórica:

\begin{abstract}
"A união afetiva constituída entre pessoas do mesmo sexo não pode ser ignorada em uma sociedade com estruturas de convívio familiar cada vez mais complexas, para se evitar que, por conta do preconceito, sejam suprimidos direitos fundamentais das pessoas envolvidas. (...) Enquanto a lei civil permanecer inerte, as novas estruturas de convívio que batem às portas dos tribunais devem ter sua tutela jurisdicional prestada com base nas leis existentes e nos parâmetros humanitários que norteiam não só o direito constitucional mas a maioria dos ordenamentos jurídicos existentes no mundo. Diante da lacuna da lei que envolve o caso em questão, a aplicação da analogia é perfeitamente aceitável para alavancar como entidade familiar as uniões de afeto entre pessoas do mesmo sexo. Se por força do art. 16 da Lei 8.213/91, a necessária dependência econômica para a concessão da pensão por morte entre companheiros de união estável é presumida, também o é o caso de companheiros do mesmo sexo, diante do emprego da analogia que se estabeleceu entre essas duas entidades familares. "(DIAS, 2011:256-257)
\end{abstract}

No ano de 2005 foi intentada uma Ação Civil Pública pelo $\mathrm{MPF}^{20}$, com o intuito do reconhecimento do casamento civil homossexual. $\mathrm{Na}$ inicial, o Procurador da República, Dr. João Gilberto Gonçalves Filho assevera que o direito a receber do Estado brasileiro o status jurídico de uma pessoa casada é uma materialização dos direitos da personalidade. Acrescenta ainda o Procurador que:

\begin{abstract}
"se é o objetivo da República Federativa do Brasil a construção de uma sociedade livre, justa e solidária, as pessoas devem ter liberdade para escolher seus parceiros sexuais sem que essa escolha implique injustas restrições de tratamento por parte do aparato administrativo estatal. A solidariedade pressupõe acolher e dar apoio às escolhas individuais, abrindo oportunidade a qualquer pessoa para que possa concretizar o seu direito constitucional de ser feliz, mormente quando essas escolhas não atrapalham em nada os direitos individuais das demais ou os direitos coletivos em geral, como é o caso do casamento dos homossexuais" (CHAVES, 2011:220)
\end{abstract} ${ }^{20}$ Processo 2005.61.18.000028-6, em trâmite perante a Justiça Federal da Comarca de
Guaratinguetá. 
A referida ação ainda aguarda julgamento, mas deverá ser julgada procedente a fim de que o Judiciário passe a obrigar a União, todos os Estados e o Distrito Federal a celebrarem o casamento civil homoafetivo, sob pena de perpetuação do preconceito concretizado em nossa sociedade. Entretanto, em outros processos já há a manifestação de magistrados no sentido de se entender viável o casamento entre pessoas do mesmo sexo no ordenamento brasileiro.

Em uma decisão de dissolução de união estável homoafetiva, o Juiz Roberto Arriada Lorea, da $2^{a}$ Vara de Família e Sucessões da Comarca de Porto Alegre- $\mathrm{RS}^{21}$, assegurou no sentido de ser possível o reconhecimento não só da união estável, mas também do casamento homossexual. Como bem explicita o Magistrado, sob a égide dos princípios estabelecidos na Carta Magna brasileira, não haveria necessidade de se justificar o direito ao casamento entre pessoas do mesmo sexo. Pelo contrário, a negativa de acesso ao instituto jurídico do casamento às pessoas homossexuais é que deveria ser justificada. Na sua concepção, não há necessidade de desdobrar tal direito aos homossexuais porque esse direito já existe. Para tanto, bastaria que houvesse um pedido formal de casamento entre duas pessoas do mesmo sexo. Argumenta ainda, que o casamento civil é um direito humano e não um privilégio heterossexual.

\begin{abstract}
"Em sua decisão afastou o juiz a preliminar de mérito do Ministério Público, que alegava que a atual redação do artigo 226 parágrafo $3^{\circ}$ da $C F 88$ vedaria a união estável homoafetiva e que haveria falta de embassamento legal que fundamentasse entendimento diverso, entendimento este que poderia acarretar 'preocupantes' reflexos fáticos. Todavia, como o MP não explicitou quais seriam esses 'preocupantes' reflexos fáticos, o magistrado descartou essa alegação, ante a ausência de provas acerca da pertinência da discriminação pretendida por aquele órgão. (...) Ademais, assevera o magistrado que a redação do artigo 226 parágrafo $3^{\circ}$ da CF 88 não proíbe, em nenhum momento, que a união estável homoafetiva possa ser protegida pelo ordenamento jurídico, tratando-se tal questão de lacuna normativa- que, como atesta, de acordo com o art 4 da LICC, deve ser resolvida pela analogia, pelos costumes e pelos princípios gerais do Direito. Assim, ante a ausência de proibição expressa na lei, aliada ao princípio da igualdade e ao fato de que deve o Direito interagir com as demais ciências, aduz o magistrado que não merece acolhimento a tese da impossibilidade
\end{abstract}

\footnotetext{
${ }^{21}$ Processo no 00118148080, $2^{\text {a }}$ Vara de Família e Sucessões da Comarca de Porto Alegre- RS.
} 
jurídica do pedido levantada pelo MP. Com relação ao mérito o MP alegou que não haveria provas suficientes da união estável dos ex-parceiros homossexuais, argumento este afastado pelo magistrado ante as provas constantes dos autos, discussão essa que não interessa ao presente trabalho, que aborda a questão da possibilidade jurídica do pedido, reconhecida pelo magistrado que julgou tal ação. (...) O magistrado é peremptório: 'À luz do artigo $3 .^{\circ}$, inciso $I V$, da Constituição Federal, conforme fundamentação supra, tenho que (não apenas a união estável, mas também) o casamento, nos moldes como atualmente regulado pelo legislador, é um instituto passível de ser acessado por todas as pessoas, independente de sua orientação sexual...' . Em decisão mais recente, afirmou o magistrado com perfeição que: 'O casamento civil é um direito humano - não um privilégio heterossexual. ’’ (VECCHIATTI, 2008:297-303)

\section{Legislação}

Muitos são os Projetos de Lei que tratam do tema da homossexualidade. O mais antigo e conhecido sobre o assunto é o de número 1.151, de 1995, de autoria da ex-Deputada Marta Suplicy, que regula a "união civil entre pessoas do mesmo sexo" sob o slogan "Um legítimo direito de cidadania". O Relator do Projeto apresentou substitutivo e, além de impor algumas limitações, alterou para "Parceria Civil Registrada".

O parecer favorável da Comissão Especial do Congresso é de 10 de fevereiro de 1996, mas é enorme a resistência, principalmente das forças conservadoras que rejeitam sua aprovação. O Projeto encontra-se no plenário, pronto para ser incluído na ordem do dia há exatos dez anos.

Como frisa Maria Berenice Dias:

"No Brasil, é constrangedor o silêncio. O Projeto de Lei 1.151, regulamentando a parceria civil registrada, data do ano de 1995 e está no Congresso Nacional desde então, sem qualquer chance de ser aprovado. Aliás, trata-se de legislação que já se encontra defasada, pois os direitos que pretendia assegurar não mais correspondem aos anseios da comunidade LGBT. A própria Justiça já confere direitos de mais amplitude. A única referência legal que temos é a Lei Maria da Penha ( Lei 11.340/2006), que define a família como uma relação intima de afeto independente da orientação sexual." (DIAS, 2009:65-66) 
De fato, a única referência legal existente é a LMP. Isso porque está afirmado em lei federal que as uniões homoafetivas constituem entidade familiar. Conforme exposto no primeiro capítulo, a LMP define entidade familiar como "qualquer relação íntima de afeto" e menciona, ainda, que tais relações independem de orientação sexual. Assim, uma lei que protege os homossexuais já existe.

Esse é o entendimento de Maria Berenice Dias no artigo "Violência Doméstica e as uniões homossexuais":

"A eficácia da lei é imediata, passando as uniões homossexuais a merecer a especial proteção do Estado (CF, art. 226). Em face da normatização levada a efeito, restam completamente sem razão de ser todos os projetos de lei que estão em tramitação e que visam a regulamentar, a união civil, a parceria civil registrada, entre outros. Esses projetos perderam o objeto uma vez que já há lei conceituando como entidade familiar ditas relações, não importando a orientação sexual de seus partícipes. No momento em que as uniões de pessoas do mesmo sexo estão sob a tutela da lei que visa a combater a violência doméstica, isso significa, inquestionavelmente, que são reconhecidas como uma família, estando sob a égide do Direito de Família. Não mais podem ser reconhecidas como sociedades de fato, sob pena de se estar negando vigência à lei federal. Conseqüentemente, as demandas não devem continuar tramitando nas varas cíveis, impondo-se sua distribuição às varas de família. Diante da definição de entidade familiar, não mais se justifica que o amor entre iguais seja banido do âmbito da proteção jurídica, visto que suas desavenças são reconhecidas como violência doméstica."

Vale destacar que encontra-se no Senado o Projeto de Lei 5.003, de 2001, que propõe sanções às pessoas físicas e jurídicas que pratiquem crime de discriminação e preconceito contra homossexuais. A ele está apensado o Projeto de Lei 122/2006, que tem o mesmo propósito de criminalizar a homofobia.

No âmbito estadual em 2007, entrou em vigor no Rio de Janeiro a Lei $\mathrm{n}^{\mathrm{0}}$ 5.034, dispondo sobre a averbação, pelos servidores públicos estaduais, da condição de companheiros do mesmo sexo, para fins previdenciários e outras providências. Assim, o Estado do Rio de Janeiro passou a conceder a pensão previdenciária através do Estatuto dos 
servidores, sendo exigida a comprovação da união estável entre o servidor (a) e o companheiro (a).

\section{Considerações Finais}

Não há dúvidas de que um novo panorama jurisprudencial mais atento à realidade da vida e à dignidade da pessoa humana começou a ser construído. Visivelmente, Tribunais de todo o Brasil começaram a aplicar os mais novos precedentes, que vêm dando justo tratamento às uniões homoafetivas, as quais nada mais são do que entidades familiares.

Com efeito, diante do silêncio do legislador, é a jurisprudência a mais importante ferramenta para assegurar aos homossexuais o exercício de cidadania. Enquanto a lei não vem, cabe ao Poder Judiciário suprir tal lacuna com uma visão pluralista das entidades familiares e isonômica das relações. De fato, essas conquistas do Judiciário estão desempenhando o papel que as leis não cumprem: tratar homossexuais e heterossexuais da mesma maneira. Afinal, é muito mais fácil fazer um juiz decidir a favor dos homossexuais do que a maioria do Congresso aprovar uma mudança de lei.

É o que dispõe a Revista Superinteressante do mês de maio, em sua página 20:

\footnotetext{
"Nos últimos anos, decisões da Justiça permitiram que gays exercessem o direito de incluir o companheiro no plano de saúde, de ganhar pensão por morte e de declarar o imposto de renda em conjunto. Essas vitórias do Judiciário estão cumprindo o papel que as leis não cumprem: tratar homossexuais $e$ heterossexuais da mesma maneira. É muito mais fácil fazer um juiz decidir a favor dos gays do que a maioria do Congresso aprovar uma mudança de lei. (...) Segundo a Comissão da Diversidade da Ordem dos Advogados do Brasil, tribunais de todo o país já reconheceram em pelo menos 1026 processos a união entre pessoas do mesmo sexo. Em muitos desses casos ficou entendido que houve união estável do casal e que, já que todos são iguais perante a lei, não haveria porque tratar os gays de forma diferente. Assim, pelas beiradas, homossexuais estão garantindo o direito de ser tratados igualmente. Mais importante do que isso: essas decisões favoráveis abrem jurisprudência, ou seja, acabam servindo de referência para outros juízes ao julgar casos semelhantes".
} 
Contudo, mesmo perante todos os avanços jurisprudenciais, é de se ressaltar que, em um país onde a lei escrita é prestigiada, torna-se imprescindível a edição de legislação específica de forma que sejam reconhecidos todos os direitos à população LGBT. Assim, os avanços podem ser muitos, mas consagrar os direitos em regras legais é, ainda, a maneira mais eficaz de construir direitos, consolidar conquistas e derrubar preconceitos.

Esse também é o entendimento de Maria Berenice Dias em seu recente artigo "União estável homoafetiva, até que enfim!", como se vê a seguir:

"O silêncio da lei, no entanto, não impediu conquistas no âmbito do Judiciário. Quer fazendo analogia com a união estável, quer invocando os princípios constitucionais que asseguram o direito à igualdade e o respeito à dignidade, a Justiça vem deferindo direitos no âmbito do Direito das Famílias e do Direito Sucessório. (...) Tudo isso, porém, não supre o direito à segurança jurídica que só norma legal confere. O silêncio é a forma mais perversa de exclusão, pois impõe constrangedora invisibilidade que afronta um dos mais elementares direitos, que é o direito à cidadania, base de um Estado que se quer democrático de direito.(...) É chegada a hora de resgatar o débito que a sociedade tem para com significativa parcela da população que não mais pode ficar à margem do sistema jurídico. Insistir no silêncio afronta o direito fundamental à felicidade o mais importante compromisso do Estado para com todos os cidadãos." 


\section{CONCLUSÃO}

"Ninguém é feliz sozinho." - Vinicius de Morais

Com a presente monografia, foi analisada a problemática atual da possibilidade jurídica do casamento homoafetivo. De fato, uma coisa é não querer casar e outra, muito diferente, é não poder casar. E é esta última assertiva que ainda deve ser combatida no Brasil no que se refere às pessoas de mesmo sexo.

Com efeito, o Direito não pode ser conivente e se apoiar em preconceitos que levam a dolorosas experiências de vida e a consequencias irrecuperáveis. Não se pode mais continuar ignorando as relações homoafetivas, cada vez mais visíveis, cada vez mais consolidadas. É preciso apreciar o amor, o afeto, a comunhão de vidas, independente de orientação sexual, como elementos essenciais e suficientes da identidade familiar.

A homoafetividade não é um desvio de personalidade, não é uma doença, muito menos um pecado, mas sim uma forma de se relacionar. É inegável que a orientação sexual não depende de uma "opção" pessoal: ninguém escolhe ser homo ou hétero, mas simplesmense se descobre de uma forma ou de outra. A sexualidade não admite opções, simplesmente se impõe. "E não apenas a realidade, mas inclusive a ficção, em novelas ou filmes, nos mostram, todos os dias, a evidência desse fato social. " ${ }^{22}$ Ignorálo é opção atual do Poder Legislativo. Infelizmente.

Entretanto, sendo um dos aspectos da identidade humana, merece proteção jurídica dos princípios constitucionais da isonomia, da dignidade da pessoa humana, da liberdade, e do seu efetivo reconhecimento pelo

\footnotetext{
${ }^{22}$ STJ, REsp 238-715 RS, rel. Min. Humberto Gomes de Barros, j.02.10.2006.
} 
princípio do pluralismo familiar. Inútil e prejudicial o entendimento de que o diferente é o errado e, portanto, deve ser modificado ou aniquilado, erradicado ou punido. Como bem proferiu o ministro do STJ Humberto Gomes de Barros em seu voto ${ }^{23}$, os homossexuais não são cidadãos de segunda categoria e, por isso, assim não devem ser tratados, sendo que a opção ou condição sexual não diminui os direitos e, muito menos, a dignidade da pessoa humana.

Ademais, condenar à invisibilidade jurídica tais uniões não eliminaria a existência da homossexualidade. Não é pela ausência de leis regulamentadoras que os homoafetivos deixariam de sê-los. Não é pela restrição de direitos que "faríamos desaparecer essa forma de relação". A omissão do legislador, pois, não tem força e legitimidade para suprimi-la até porque tais uniões existem em todos os sentidos, menos no legal.

Sobre tal ponto, com muita propriedade se manifesta Maria Berenice Dias:

"A identidade sexual das partes não pode impedir que se veja a realidade. Mascarar a realidade não irá solucionar as questões que, mais do que sociedades de fato, constituem sociedades de afeto, o mesmo liame que enlaça os parceiros heterossexuais. De outro lado, considerar uma relação afetiva de duas pessoas do mesmo sexo como uma entidade não vai comprometer a estabilidade social, acabar com a família e nem desestimular casamentos. Também não vai levar ao aumento da prática homossexual. Apenas permitirá que um maior número de pessoas saia da clandestinidade, deixando de ser marginalizada" (DIAS, 2009:33)

Nestas condições, uma lei institucionalizando o casamento entre pessoas do mesmo sexo viria apenas para reforçar e legitimar um fato real, atual e merecedor de tutela. Cidadãos como outros quaisquer, que pagam impostos e muito contribuem para o desenvolvimento social, não mais

\footnotetext{
${ }^{23}$ STJ, REsp 238.715-RS, $3^{\text {a }}$ T. Rel. Min. Humberto Gomes de Barros, j. 07.03.2006. Em tal julgamento foi admitida a inclusão do companheiro como dependente em plano de assistência médica.
} 
podem ser discriminalizados por lhes ser atribuído o erro de amarem quem os atrai. Evidente, pois, a necessidade de encarar a realidade em comprometimento com a Justiça, não punindo alguém pelo simples fato de amar o igual e reivindicar, como todos os demais, o direito de ser feliz.

De qualquer maneira, conforme demonstrado neste estudo, essa ausência legislativa não teria o condão de afastar a possibilidade do casamento homoafetivo, em razão da sua viabilidade pelo caminho da analogia e da interpretação extensiva. E, inobstante a postura conservadora de boa parte da doutrina, nota-se uma mudança de orientação jurisprudencial com significativos avanços, conforme destacado no sexto capítulo deste trabalho.

A Lei Maria da Penha, analisada no primeiro capítulo, reconheceu expressamente a família homoafetiva, ao definir que também é famíla, duas mulheres que se considerem unidas, independente da orientação sexual, e que formem uma comunhão plena de vida de forma pública, contínua e duradoura nos moldes do artigo 1.723 do CC. Assim, considerando que as uniões homoafetivas femininas e masculinas têm caráter familiar idêntico, pelo princípio da isonomia, dois homens na mesma situação também seriam família.

Nestas circunstâncias, é importante e essencial que o Estado, através de leis, retire definitivamente tais relações da marginalidade e as consagre. Afinal, o Direito, que é um importante instrumento ideológico de inclusão que se constitui como um dos lugares de realização da luta por um reconhecimento, não regula sentimentos mas deve definir as relações com base neles geradas. Aliás, a simples observação sobre a vida social confirma que a diversidade é a regra da modernidade. E não é só isso: devemos, também, reconhecer o fato de que não ser heterossexual ou não ser homossexual é direito de todos. 
Gostaria de encerrar o presente trabalho com as ilustres palavras de Chico Xavier:

"A gente pode

morar numa casa mais ou menos,

numa rua mais ou menos,

numa cidade mais ou menos

e até ter um governo mais ou menos

A gente pode

dormir numa cama mais ou menos,

comer feijão mais ou menos,

ter um transporte mais ou menos,

e até ser obrigado a acreditar mais ou menos no futuro.

A gente pode

olhar em volta e sentir que tudo está

mais ou menos.

Tudo bem

O que a gente não pode

mesmo, nunca, de jeito nenhum,

é amar mais ou menos,

é sonhar mais ou menos,

é ser amigo mais ou menos,

é namorar mais ou menos,

é ter fé mais ou menos,

e acreditar mais ou menos.

Se não a gente corre o risco de se tornar

Uma pessoa mais ou menos."

- Chico Xavier - 


\section{REFERÊNCIAS BIBLIOGRÁFICAS}

BARROSO, Luís Roberto. Interpretação e aplicação da Constituição, $6^{\mathrm{a}}$ Edição, São Paulo: Editora Saraiva, 2006, Cit. p. 228-229.

CHAVES, Marianna. Homoafetividade e Direito: Proteção Constitucional, Uniões, Casamento e Parentalidade: Um Panorama Luso-Brasileiro. Curitiba: Editora Juruá, 2011. 332p.

DIAS, Maria Berenice. Manual de Direito das Famílias. $4^{\mathrm{a}}$ ed. rev., atual. e ampl.. São Paulo: Editora Revista dos Tribunais, 2007. 610p.

DIAS, Maria Berenice. União Homoafetiva: O preconceito \& a justiça. $4^{\mathrm{a}}$ Edição. São Paulo: Editora Revista dos Tribunais, 2009. 320p.

DIAS, Maria Berenice. Diversidade Sexual e Direito Homoafetivo. São Paulo: Editora Revista dos Tribunais, 2011.571 p.

EINSTEIN apud ALMEIDA, Aline Mignon de. As uniões homoafetivas como forma de construir família. In: VIEIRA, Tereza Rodrigues (org.). Bioética e sexualidade, $1^{\mathrm{a}}$ Edição, São Paulo: Editora Jurídica Brasileira, 2004, Cit, p 71.

FARIAS, Cristiano Chaves de. Escritos de Direito de Família. Rio de Janeiro: Lumen Iuris, 2007. Cit, p. 132-133.

FILHO, Waldyr Grisard. Famílias reconstituídas: novas uniões depois da separação. São Paulo: Revista dos Tribunais, 2007. Cit, p.62. 
HELMINIAK, Daniel A.. $O$ que a Bíblia realmente diz sobre a homossexualidade. Trad. Eduardo Teixeira Nunes. São Paulo: Summus, 1998. 144p. Título original: What the Bible really says about homosexuality. Cit, p. 20.

HESSE, Konrad. A força normativa da Constituição. Trad. Gilmar Ferreira Mendes. Porto Alegre: Fabris, 1991, Cit. p.22-23.

LÔBO, Paulo Luiz Netto. Entidades familiares constitucionalizadas: para além do numerus clausus. Família e cidadania. O novo CCB e a Vacatio Legis. Belo Horizonte: Del Rey, 1999, Cit. p. 103.

LÔBO, Paulo. Direito Civil: Famílias, $1^{\mathrm{a}}$ Edição, São Paulo: Editora Saraiva, 2008, Cit., p.59.

LOREA, Roberto Arriada. A influência religiosa no enfrentamento jurídico de questões ligadas à cidadania sexual: Análise se um Acórdão do Tribunal de Justiça do RS, in RIOS, Roger Raupp (org). Em defesa dos direitos sexuais. $1^{\text {a }}$ Edição, Porto Alegre: Editora Livraria do Advogado, 2007, Cit. p. 38.

LOREA, Roberto Arriada. $O$ assédio religioso, in: LOREA, Roberto Arriada. (org.) Em defesa das Liberdades Laicas. Porto Alegre: Livraria do Advogado, 2008. p. 160, Cit. p.132.

LOREA, Roberto Arriada. Intolerância Religiosa e Casamento Gay, in DIAS, Maria Berenice (org.), Diversidade Sexual e Direito Homoafetivo. $1^{\text {a }}$ Edição, São Paulo: Editora Revista dos Tribunais, 2011, Cit. p. 41. 
MELLO, Celso Antônio Bandeira de. Conteúdo Jurídico do Princípio da Igualdade. $3^{\mathrm{a}}$ Edição, $11^{\mathrm{a}}$ Tiragem, São Paulo: Malheiros Editores, Maio, 2003, Cit.p.184.

PEREIRA, Rodrigo da Cunha. Direito de Família: uma abordagem psicanalítica, $2^{\text {a }}$. Ed. rev. atual. Ampl. Belo Horizonte. Del Rey, 2003a, Cit., p. 94.

PEREIRA, Rodrigo da Cunha. "Família, Direitos Humanos, Psicanálise e Inclusão Social”, em Direito de Família e Psicanálise: rumo a uma nova epistemologia, coord. GROENINGA, Giselle Câmara e PEREIRA, Rodrigo da Cunha, Rio de Janeiro: Imago, 2003b, Cit, p. 161.

RIOS, Roger Raupp. O princípio da igualdade e a discriminação por orientação sexual.Porto Alegre: Editora Revista dos Tribunais, 2002, Cit., p. 132.

SARMENTO, DANIEL. Casamento e União Estável entre Pessoas do mesmo Sexo: Perspectivas Constitucionais, in "Igualdade, Diferença e Direitos Humanos", 2008, Lumen Júris, Cit p. 649-652.

VECCHIATTI, Paulo Roberto Iotti. Manual da Homoafetividade: Da possibilidade jurídica do casamento civil, da união estável e da adoção por casais homoafetivos. São Paulo: Método, 2008. 591p.

WELTER, Belmiro Pedro. Igualdade entre a filiação biológica $e$ socioafetiva. In: Revista Brasileira de Direito de Família. Porto Alegre, a. IV, n. 14, jul./ago./set. 2002. Cit, p.237.

\section{Revistas:}

SUPER INTERESSANTE. Editora Abril. Edição 291, maio 2011. 
REVISTA JURÍDICA CONSULEX. Editora Consulex. Edição 323, julho 2010 .

\section{Julgados:}

TSE, REsp Eleitoral $n^{\circ}$ 24564/Viseu-PA. Procuradoria Regional Eleitoral no Pará e outros versus Maria Eulina Rabelo de Sousa Fernandes. Relator Min. Gilmar Ferreira Mendes. Acórdão de 01 de out. de 2004). Disponível http://www.tse.gov.br/internet/jurisprudencia/index.htm>. Acesso em 05 maio 2011.

STJ, REsp no 820.475 - RJ (2006/0034525-4). Relator Min. Antônio de Pádua Ribeiro. Acórdão de 02 de set. de 2008. Disponível em http://ww2.stj.jus.br/revistaeletronica/ita.asp?registro=200600345254\&dt_p $\underline{\text { ublicacao }=06 / 10 / 2008}$. Acesso em 05 maio 20011.

STF, ADI no 3300 - DF. Relator Min. Celso de Mello. Acórdão de 03 de $\begin{array}{lllll}\text { fevereiro } & \text { de } & 2006 . & \text { Disponível }\end{array}$ http://www.stf.jus.br/portal/jurisprudencia/listarConsolidada.asp. Acesso em 11 de março de 2011.

STJ, REsp n 395.904 - RS, 6T. Relator Min. Hélio Quaglia Barbosa. Acórdão de 13 de dez. de 2005. Disponível em http://www.stj.jus.br/SCON/jurisprudencia/toc.jsp?tipo_visualizacao=null\& processo=395904\&b=ACOR. Acesso em 15 de maio de 2011.

\section{Sites Eletrônicos:}

www.mariaberenicedias.com.br - Sessão de Artigos. "Amor não tem sexo", "União estável homoafetiva, até que enfim!”, "Violência Doméstica e as uniões homoafetivas" $e$ "A invisibilidade das uniões homoafetivas e a omissão da Justiça. Acesso em 28 de abril de 2011 e 19 de maio de 2011. 


\section{ANEXO DE FIGURAS}

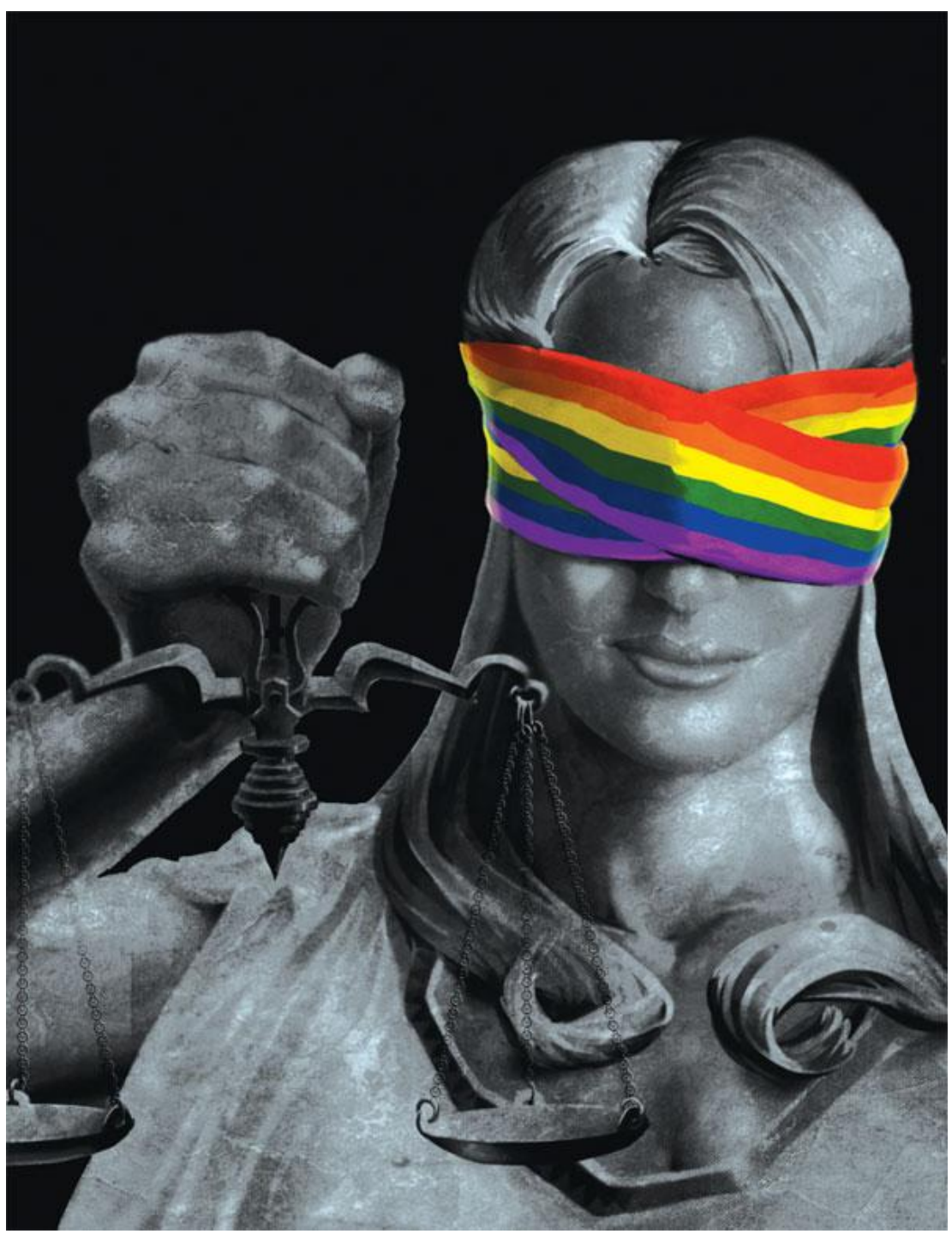

Figura 1- LGBT desvendando a Justiça. 